\title{
Towards Impact of Modified Atmosphere Packaging (MAP) on Shelf-Life of Polymer-Film-Packed Food Products: Challenges and Sustainable Developments
}

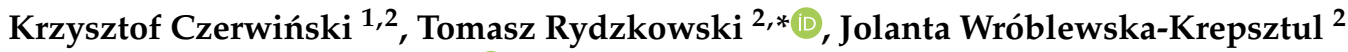 \\ and Vijay Kumar Thakur $3,4, *$ D
}

check for

updates

Citation: Czerwiński, K.; Rydzkowski, T.; Wróblewska-Krepsztul, J.; Thakur, V.K. Towards Impact of Modified Atmosphere Packaging (MAP) on Shelf-Life of Polymer-Film-Packed Food Products: Challenges and Sustainable Developments. Coatings 2021, 11, 1504. https://doi.org/ 10.3390/coatings11121504

Academic Editor: Maria

Cristina Tanzi

Received: 29 September 2021 Accepted: 29 November 2021 Published: 6 December 2021

Publisher's Note: MDPI stays neutral with regard to jurisdictional claims in published maps and institutional affiliations.

Copyright: (c) 2021 by the authors. Licensee MDPI, Basel, Switzerland. This article is an open access article distributed under the terms and conditions of the Creative Commons Attribution (CC BY) license (https:// creativecommons.org/licenses/by/ $4.0 /)$
1 WITT Polska Sp. z o.o., ul. Bulwar Dedala 16a, 54-130 Wroclaw, Poland; czerwinski@wittgas.com

2 Department of Mechanical Engineering, Faculty of Food Industry Processes and Machinery, Koszalin University of Technology, Raclawicka Str. 15-17, 75-620 Koszalin, Poland; jolaw860820@wp.pl

3 Biorefining and Advanced Materials Research Center, Scotland's Rural College (SRUC), Kings Buildings, Edinburgh EH9 3JG, UK

4 School of Engineering, University of Petroleum and Energy Studies (UPES), Dehradun 248007, India

* Correspondence: tomasz.rydzkowski@tu.koszalin.pl (T.R.); vijay.thakur@sruc.ac.uk (V.K.T.)

\begin{abstract}
In this article, we report in detail the use of protective gases to extend the shelf-life of polymer-film-packed foodstuff and reduce the most typical bacteria and microorganisms that negatively affect the quality and lifetime of a given packaging. This article provides significant information about the most important advantages of using protective gases and examples of gases or gas mixtures which can be used for almost every kind of foodstuff depending on the application. We also discuss how protective gases change the level of microorganisms in food using gases and how the shelf-life of food can be enhanced using correct gases or gas mixtures. The article also provides imperative information on the selection of correct protective gases for specific applications, especially for food production, to preserve against the most typical threats which can appear during the packaging or production process. Packaging innovations can reduce the environmental impact of food and polymer packaging waste by prolonging products' shelf-lives and by reducing waste along the production and distribution chain and at the household level.
\end{abstract}

Keywords: polymer film; shelf-life; deterioration; MAP; active packaging; quality control

\section{Introduction}

Nowadays, all food has to be fresh and healthy-meaning that it is without chemical improvers, is minimally processed, and is attractively packaged. The issue of the environmental friendliness of products, especially packaging, is of great importance. Food packaging very quickly becomes a nuisance waste [1-4]. Even though that some elements of packaging are only a matter of individual taste, the remaining elements are really important for every one of us and have to be produced at the highest level. Today's consumers require fresh food, meaning that the time between the food being made and its use by the consumer has to be as short as possible. To ensure the fastest possible delivery, the whole delivery chain has to work correctly without any redundant delays [5,6]. Furthermore, in regard to health, we are cautious when it comes to artificial additives because everybody wants to avoid poisoning. So, from the moment when fruits are picked, corn or any other grain are harvested, and fish are caught, the race against time begins. Every minute thereafter brings us closer to the time that these foods will not be suitable for consumption because of microbiological contamination such as bacteria or just because of odor $[7,8]$. To effectively extend this time, some critical conditions have to be met [9]. Parameters such as water activity, $\mathrm{pH}$ value, and type and quantity of microorganism, which are internal factors, have a really big impact on natural deterioration and the decrease in quality and shelf-life of foodstuffs. Besides internal factors, there are external factors as well, such as 
hygienic conditions while processing, proper polymer packaging film, temperature, etc., that also threaten a product's freshness $[9,10]$.

To prevent the development of bacteria or any other microorganism and extend the shelf-life of foodstuffs without using chemical additives, many years ago, protective/shielding gases began to be used, colloquially called MAP gases, which means modified atmosphere packaging $[5,11-13]$. Thanks to these gases, we do not have to use chemical additives because the surrounding atmosphere wrapping the product protects it against microbes and creates appropriate external conditions as well [7]. MAP can delay food's inherent biochemical and microbiological spoilage mechanisms, thereby imparting a preservative effect without the use of chemical additives [14].

The main aim of this article is to collect and present basic and advanced information related to the packaging of various types of food in polymer film packaging and protective gas atmospheres, as well as classic and modern techniques of packaging quality control, i.e., packaging tightness and the composition of the protective atmosphere inside the packaging.

\section{How MAP Works}

The use of MAP gases means that the standard natural air which surrounds us is taken out of packages and a specific gas or the gas mixture, usually nitrogen and carbon dioxide, is insufflated in its place $[15,16]$. Packing food in a protective atmosphere keeps the quality of fresh produce for a long time, extends shelf-life, and gives food manufacturers admittance to a potentially bigger market for products with a short shelf-life. MAP gases are suitable for use in foodstuffs in typical food groups, for example, sausages and different kind of meat, vegetables and fruits, almost every type of dairy product, bread, fish or seafood, and any other products. The requirements regarding the packaging process in case of packages with MAP gases are quite high and only those producers who control the packaging process can create securely packed food. Therefore, food producers have to use the newest technology of protective gases and multi-level quality assurance to reach the highest level of process safety [7]. However, each protective atmosphere must be optimized for a specific product, since agricultural products have different metabolisms to each other, and the MAP system must balance the processes of respiration, transpiration, and gas permeation through the packaging that will be occurring simultaneously [1]. A similar situation also applies to meat and other products we want to pack into MAP.

There are many advantages to using MAP gases, such as extended shelf-life and better quality because foodstuffs packaged in this special atmosphere pollute much slower, and when we combine this with continuous cooling, then we get highly prolonged freshness of consumable products. Modified atmosphere packaging (MAP) along with low temperature storage extends the shelf-life of fresh produce packaged in polymeric films through the interaction of the natural process of respiration of produce with the restricted gas exchange across the package [17]. Of course, it depends on the product type, but in most cases, we can even double the shelf-life [18]. Usually, MAP products have the highest possible quality for a long time and reach consumers in the best condition that can be provided. Another advantage which we get with MAP is less waste because of the shielding gases; MAP causes much fewer problems with long-distance transport and extends the consumable time of foodstuffs [19]. Due to MAP, it is easy to limit waste, which corresponds to several kilograms of spoiled food and packaging films. This advantage means that producers can open up to new geographic markets to get to new customers, which we can observe through globalization. Another big benefit of MAP is stopping or at least decreasing preservative use. Packaging with a protective atmosphere prolongs the shelf-life, which is the same role of preservatives (Figures 1 and 2, Table 1). In many cases, this means that preservatives can be highly limited or even eliminated, and customers receive products without artificial additives [20]. Of course, there are also studies that show the combination of chemical treatment and MAP is more useful for inhibiting the growth of bacteria and yeast [21]. 


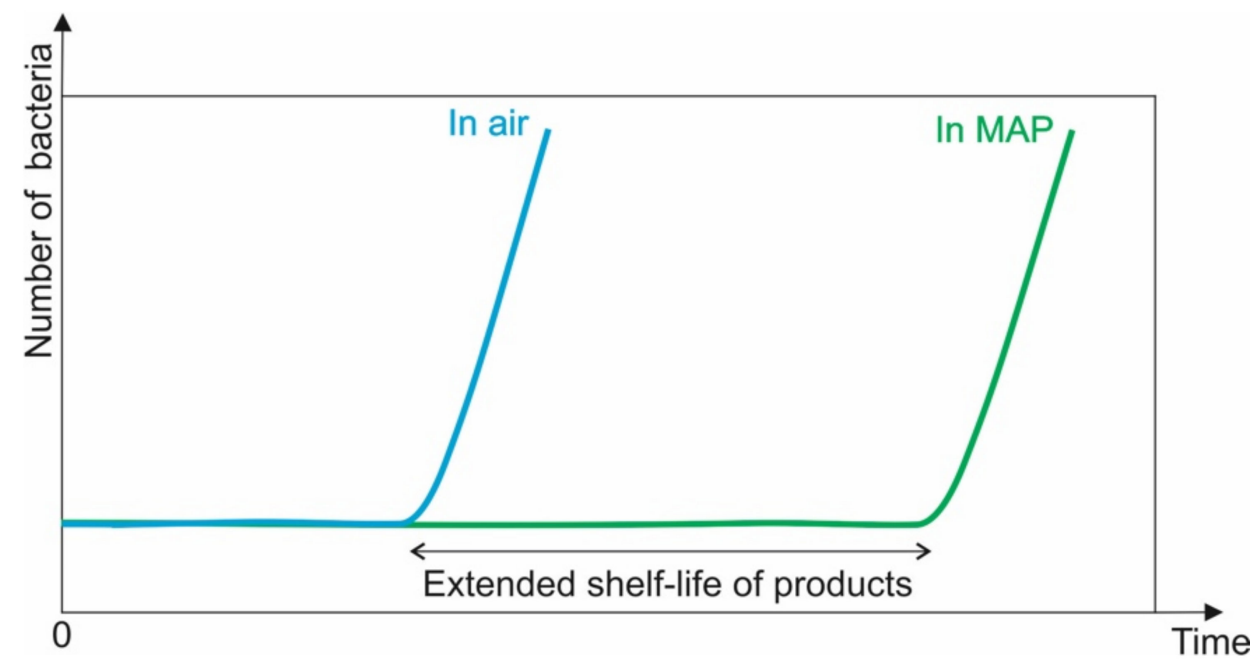

Figure 1. The difference between shelf-life of products with and without MAP gases, reprinted with permission from WITT Polska.

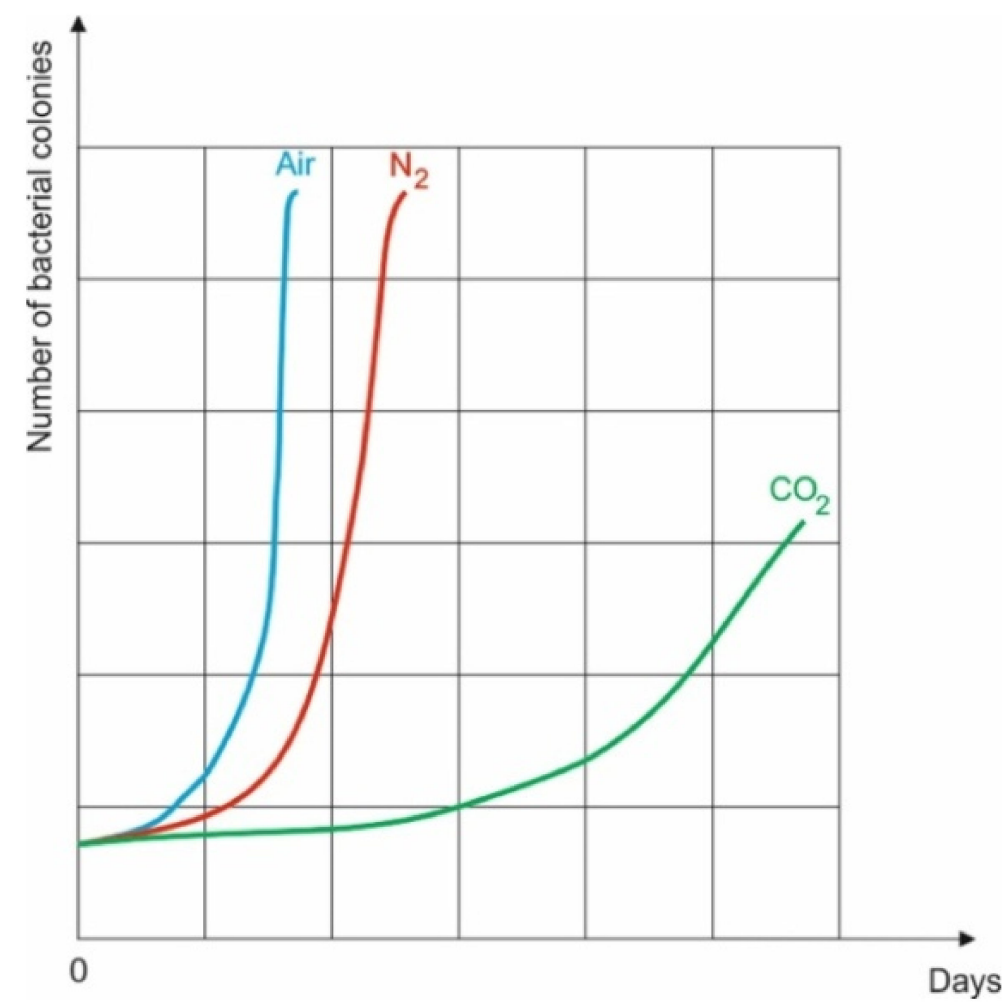

Figure 2. Bacterial colony numbers increasing on pork with or without MAP gases in stable low temperature $\left(3-5{ }^{\circ} \mathrm{C}\right)$, reprinted with permission from WITT Polska.

Following the initial recognition of the advantage of CA (controlled atmosphere) storage over standard refrigerated air storage, several significant advances have taken place in the technologies and strategies for atmosphere control. These include the use of $\mathrm{CO}_{2}$ scrubbing techniques to control $\mathrm{CO}_{2}$ levels, improved technologies for generating low $\mathrm{O}_{2}$ atmospheres, the development of sense-and-respond systems for atmosphere control, and innovations in atmosphere control protocols. The huge amount of carbon dioxide is one of the main factors causing global warming. In order to limit its negative impact on the climate and atmosphere, modern companies oblige themselves to reduce their carbon footprint by reducing $\mathrm{CO}_{2}$ emissions. An excellent way to reduce $\mathrm{CO}_{2}$ is to recycle waste 
efficiently. It is already necessary to implement effective waste management that will allow for the effective reduction in carbon footprints, reducing the emission of $\mathrm{CO}_{2}$ and other greenhouse gases [7].

Table 1. The shelf-life list of different products with or without MAP gases.

\begin{tabular}{|c|c|c|}
\hline Food & $\begin{array}{l}\text { Shelf-Life in Air } \\
\text { (Days) }\end{array}$ & $\begin{array}{l}\text { Extended Shelf-Life in the } \\
\text { Correct MAP Gas Mix } \\
\text { (Days) }\end{array}$ \\
\hline Bread & few days & $7-14$ \\
\hline Cakes & several dozen days & even 365 \\
\hline Cooked fish & up to 4 & up to 28 \\
\hline Dried foods & up to 240 & up to 730 \\
\hline Fresh cut salad mix & up to 5 & up to 10 \\
\hline Fresh pasta & up to 14 & up to 28 \\
\hline Hard cheese & up to 21 & up to 70 \\
\hline Pies & up to 5 & up to 21 \\
\hline Pizza & up to 10 & up to 28 \\
\hline Pre-baked bread & up to 5 & up to 20 \\
\hline Raw dark poultry & up to 5 & up to 14 \\
\hline Raw fish & up to 3 & up to 9 \\
\hline Raw light poultry & up to 7 & up to 21 \\
\hline Ready meals & up to 5 & up to 20 \\
\hline Raw red meat & up to 4 & up to 8 \\
\hline Sandwiches & up to 3 & up to 10 \\
\hline Sausages & up to 4 & up to 35 \\
\hline Slicked cooked meat & up to 4 & up to 35 \\
\hline Soft cheese & up to 14 & up to 21 \\
\hline
\end{tabular}

*All values-approximate values.

Besides these advantages, there are some limitations to using protective gases. The first and one of the most important is that the use of protective gases has comparatively high complexity, meaning that the packaging process regarding MAP gases has quite high requirements [7]. The typical failure which can happen is, for example, incorrect gas concentration, lack of tightness because of wrong temperature or incorrect pressure, damaged parts of packaging machines or tools, leftover products at the seals, or problems with materials such as the wrong film, etc. However, most of them can be eliminated using the best-quality equipment and correct maintenance actions [20]. Another limitation is the much higher cost of using protective gases compared to the use of chemical additives, especially with regard to not only gas costs, but additional quality control materials or special high-quality film costs as well. However, it is possible to minimize the mainstream of the costs thanks to effective resources management. The last issue which can discourage the use of MAP is the influence of gases on meal taste when we use, for example, a high level of $\mathrm{CO}_{2}$ concentration which reacts with the products and makes food sour. Wherein, this effect is possible to reduce by using special gas mixtures which can be adapted to requirements. In some of the literature, there is evidence that MAP gases make meat chewier, but there is no sure proof of this [18]. So, that is why there is a need for the commercial application of technology by processors and fresh produce retailers. Additionally, there is a need for MAP and related technology research for local crops under local conditions in developing countries [22].

\section{The Protective MAP Gases}

Typical gases which can be easily used with food, especially as MAP gases, mainly include carbon dioxide and nitrogen. These gases can occur both as a single gas or together as a gas mix. It is also possible to use gases such as carbon monoxide, argon, or in some cases, oxygen $[5,7,10,23,24]$. 
The most used gas is carbon dioxide, which is colorless, odorless, and tasteless. Its main role is to limit oxidation and stop the growth of aerobic bacteria and mold (Figure 2). Atmospheres containing $\mathrm{CO}_{2}$ effectively increase the storage period of meat products by reducing microbial growth [25]. It is also important to mention that it is also responsible for the extension of shelf-lives. Normally, it seems that the length of shelf time is directly proportional to the level of carbon dioxide inside the package. So, put simply, the shelf-life is longer when there is more carbon dioxide [5]. Unfortunately, it has a disadvantage because it results in souring. Some products can change in taste and become sour because of the too-high level of carbon dioxide, so that is why it is really important to keep the balance. Moreover, carbon dioxide can react with film or any other materials and finally, with the products, which can be a reason why packages start to collapse. Because of this reason, in most cases, carbon dioxide is used together with other gases in a gas mix, such as, for example, with nitrogen [26].

Thanks to nitrogen, it is possible to make gas mixes where its main role is to substitute the air in food packaging, particularly oxygen contained in the air. Generally, these gas mixes are made up of a pure and an inert gas, which prevents food oxidation and stops the growth of aerobic microorganisms. Nitrogen is mostly used as balance or rest gas. The dispersion of nitrogen is quite slow, and the assumed level of nitrogen stays longer in the packaging [5,7].

One another interesting kind of gas is oxygen, which is normally not used with food because oxygen causes the breakdown of food, as oxidation and shaping provide perfect conditions for the growth of aerobic microorganisms. So, that is why oxygen is not often used in the MAP gases. As research has shown, the greatest extension of shelf-life occurs at the lowest possible oxygen concentration before anaerobic respiration is initiated [9]. There is only one situation when oxygen is used with food, and that is when one wants to obtain the perfect red color of meat and inhibit the growth of anaerobic organisms. Subsequently, we have to treat red meat with a high level of oxygen [27-30].

In addition to the gases described above, there are other gases which can be used in food processing, such as argon, which is an inert, colorless, odorless and tasteless gas. In some ways, it is similar to nitrogen; some research has shown that argon slows metabolic reactions in some types of vegetables. However, based on the price comparison of nitrogen and argon and despite this marginal advantage of argon, nitrogen is much more popular. It is almost impossible to find noble gases_-which argon is_-in food packaging [5]. The next gas which is also sometimes used in food is carbon monoxide. To extend the red color stability and avoid the drawbacks of aerobic packaging, an anaerobic MAP technology with $0.4 \%$ CO (CO-MAP) was approved for use with fresh meats in the USA [31]. The US Food and Drug Administration approved 0.4\% CO in MAP master packs (USFDA, 2002) and in primary packages (USFDA, 2004) [32]. However, in many countries, and even in the EU, the use of this with food as a component of modified atmosphere is prohibited, despite the subjective and objective color analyses that indicated, as has been well-documented [32,33], that CO in MAP stabilized red meat color throughout its shelf-life, regardless of temperature [34]. This is probably why some studies have shown that the use of $\mathrm{CO}$ in meat packaging systems in the EU should be re-evaluated, as outlined in recent work by Van Rooyen [35], as CO pre-treatments can be tailored to ensure that the meat color becomes unacceptable prior to the meat becoming spoiled so that consumers are not misled about the safety of the meat on display [31]. Carbon monoxide is similar to argon, a colorless, odorless and tasteless gas, and it is similar to oxygen as it is used to keep red meat red, with a small difference in that the required concentrations are very low compared to oxygen [7]. After some research, it was found that increasing oxygen levels in modified-atmosphere packaging from $20 \%$ to $80 \%$ increases color stability. The inclusion of $0.4 \%$ carbon monoxide in conjunction with these oxygen levels d not influence color stability, metmyoglobin-reducing activity, or oxygen consumption [32].

Gases such as helium and hydrogen are not used to extend the shelf-life of food. So far, noble gases such as helium or hydrogen are extremely rarely used, probably because 
of the high price. In most cases, they are used as the trace gases in leak detection systems because of the tiny molecular size. They allow fast escape through potential leaks points and quickly recognize the leaks [7,36-39].

\section{MAP-Protective Gas Atmosphere in the Packaging of Selected Product Types}

Modified atmospheres can be used in a very broad area of food production (Table 1). Until now, usually, bread, dairy, or meat products were packaged with a protective atmosphere, but in the last few years, MAP is increasingly being used for other products such as coffee, kinds of seafood and fishes, and fruit and vegetables. However, these are not all the products where modified atmosphere packaging can be used, because MAP is becoming very popular in ready-made meals or convenience products. Packaging in a modified atmosphere lengthens the shelf-life of fresh products. This technology allows for longer storage in this specific atmosphere, i.e., with reduced $\mathrm{O}_{2}$ rest and increased $\mathrm{CO}_{2}$ compared to air. Modified atmospheres reduce the rate of breathing and ethylene production, which in effect slows down physiological processes and, consequently, slows down the degeneration of products $[10,40]$. Molecular changes are caused by a series of enzymatic reactions that take place in the metabolic tract, for example, glycolysis, the tricarboxylic acid cycle, and the electron transport system. Modified atmospheres (MAPs) are created actively or passively. In the active modification, the atmosphere is created by flushing the main space with the desired mixture of gases. In the case of passive rejuvenation, the atmosphere is created by allowing the product to respire inside the package, slowly establishing the balance. In both cases, the atmosphere is maintained by the dynamic balance of breathing and penetration [41].

\subsection{Meat Products including Sausage and Poultry}

Meat products, such as sausage and raw meat, are susceptible to spoilage because of microbial growth, high moisture, and high nutrient content $[12,25]$. No matter whether the product is beef, pork, or poultry [42], the spoilage process begins directly after the moment of butchering [43]. Despite the high suspended hygiene standards of quality and constant cooling, MAP atmospheres can prolong the shelf-life of almost every meat product [34]. $\mathrm{CO}_{2}$ is the most important among the protective gases [44]. MAP gas mixed with concentrations of more than $20 \%$ of $\mathrm{CO}_{2}$ allows for significant reductions in microbial growth [45].

Considering red meat, we certainly encounter the problem of the oxidation of red color dye [35]. The red color of meat will disappear, becoming grey and not attractive for the potential customer. The oxidation is very noticeable for beef. So, that is why a high level of oxygen in MAP gas could be very helpful to avoid oxidation $[14,46,47]$. Retail packaging of meat in modified atmospheres (MAs) with $70-80 \%$ oxygen is used to provide a stable bloomed red meat color, which is attractive to the consumer. The inclusion of $20-30 \%$ carbon dioxide $\left(\mathrm{CO}_{2}\right)$ prolongs the shelf-life by inhibiting bacterial growth $[46,47]$. At the same time, the low carbon monoxide level (about $0.5 \%$ ) is also able to help to keep the red hue of meat [32,35]. However, the use of carbon monoxide is prohibited in the EU, as mentioned earlier.

Modified atmosphere packaging (MAP) is considered as an effective method for packaging various fresh meat and related products, including chicken meat, in order to extend the shelf-life of products. The use of an optimal mixture of gases $\left(\mathrm{CO}_{2}, \mathrm{~N}_{2}\right.$, and $\left.\mathrm{O}_{2}\right)$ in food packaging containers has been proved to effectively inhibit the microbial flora of various fresh perishable food, such as poultry meat [48].

Poultry is highly receptive to quick spoilage and is therefore subject to much higher requirements for uninterrupted cooling [49]. In this case, too, a MAP containing $\mathrm{CO}_{2}$ certainly will prolong the shelf-life (Figure 3). A high level of oxygen is also used for poultry with no skin to keep the hue of the meat. We have to also remember that $\mathrm{CO}_{2}$ can partly be absorbed into products [50]. To avoid the packages from collapsing, usually, nitrogen is used as the balance gas [13]. 


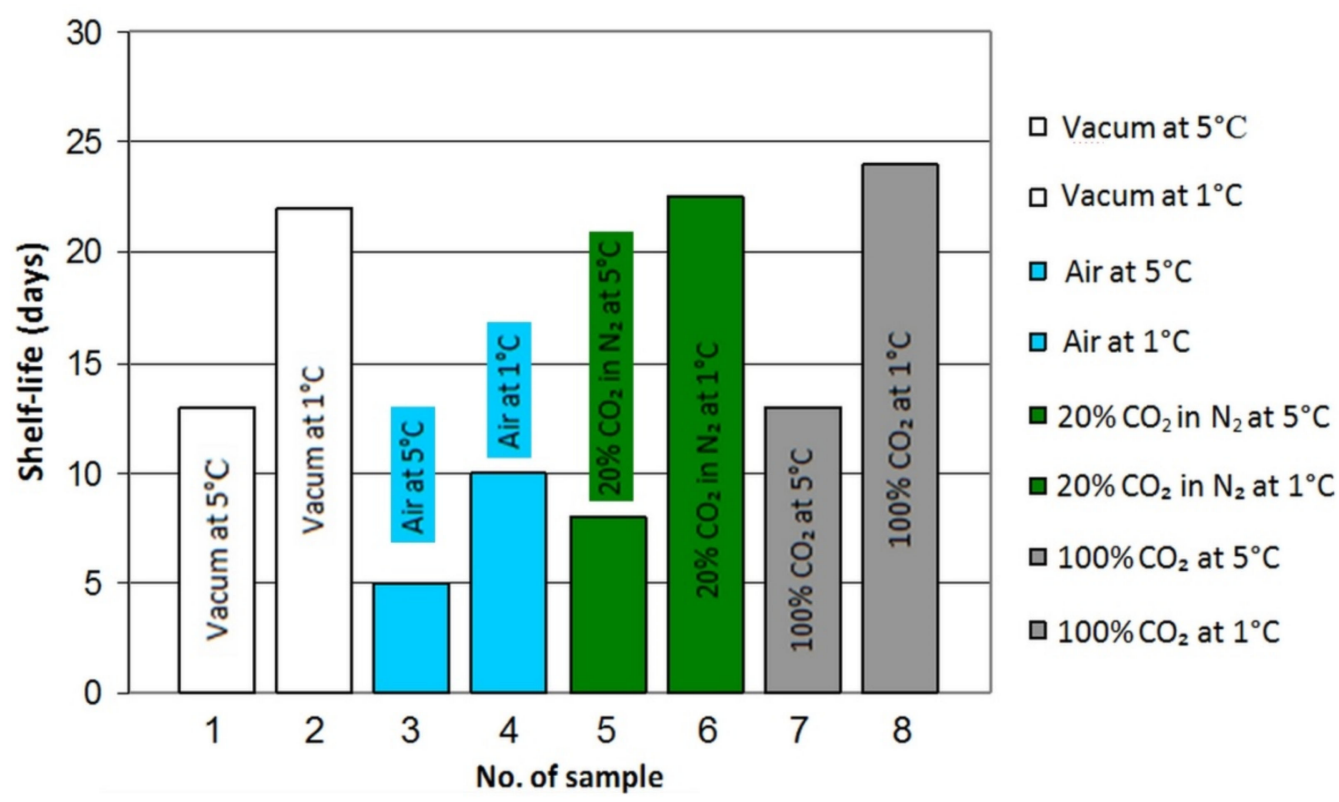

Figure 3. Chicken's meat shelf-life in different temperature and gas mix combinations, reprinted with permission from WITT Polska.

Products such as meat and sausage, e.g., smoked and marinated meat pieces, react differently depending on the different gas mixes [51,52]. The extended shelf-lives of products are possible to attain by the use of MAP gases from the beginning of the production process. As research has shown, all the investigated MAPs showed an antimicrobial effect; moreover, low carbon dioxide concentrations caused a lower color variation during storage [52]. However, we have to remember that a too-high level of $\mathrm{CO}_{2}$ in the packaging process of these products will create a sour taste $[30,48]$. The same situation takes place in the case of raw meat, especially pork meat. Although high-oxygen MAPs stabilize fresh beef color, the effect in pork is inconsistent because give rise to the formation of undesirable off-flavors and odors [51].

High concentrations of oxygen have also been shown to increase lipid oxidation in meat and meat products, causing rancidity [28-30].

\subsection{Sea Products Like Fish and Seafood}

The most sensitive foods certainly belong to seafood and fish (Figure 4). This happens because directly after being caught, seafood products quickly spoil and decrease in quality. So, what is the reason for this? Generally, the $\mathrm{pH}$ value, which is neutral, causes them to spoil quickly, and $\mathrm{pH}$ contributes to the existence of a great precondition for microorganisms such as particular enzymes which ensure bad taste and odor. The next problem for fish, especially those which contain fatty acids, is quite fast rancidity. That is why, for an extended shelf-life, it is really important to keep these items cool, very close to $0^{\circ}$ Celsius. Moreover, MAP gases with $\mathrm{CO}_{2}$ levels above $20 \%$ greatly stop the increasing number of bacteria as well. In fact, it is generally recognized that in the absence of $\mathrm{O}_{2}$ and in the presence of $\mathrm{CO}_{2}$, a bacteriostatic effect is exerted on aerobic microflora, thus inhibiting Gram-negative bacteria, such as Pseudomonas spp. and hydrogen sulfide-producing bacteria [53]. The popular practice is the use of a gas mix with a $50 \% \mathrm{CO}_{2}$ level [54]. When we use higher $\mathrm{CO}_{2}$ concentrations, we have to reckon with undesirable effects such as unwanted sour tastes and dry products. Sometimes, higher $\mathrm{CO}_{2}$ concentrations are used as well as $\mathrm{O}_{2}$ in the gas mix for low-fat fish and shellfish. This procedure enables the correct color to be kept, and on the other hand, works favorably for some forms of bacteria. However, for products such as shellfish or crustaceans, it is really important to not exceed a high level of $\mathrm{CO}_{2}$. There is clear evidence of too-high $\mathrm{CO}_{2}$ levels causing sour tastes of the product and collapsed packaging because of the $\mathrm{CO}_{2}$ absorption by the product. To 
avoid this situation and effect, usually, nitrogen is used as the inert gas to fill the packs. Besides $\mathrm{CO}_{2}$, there is the possibility to interact with carbon monoxide, which is also used interchangeably, but only in countries where carbon monoxide is approved to be used as an MAP gas [31].

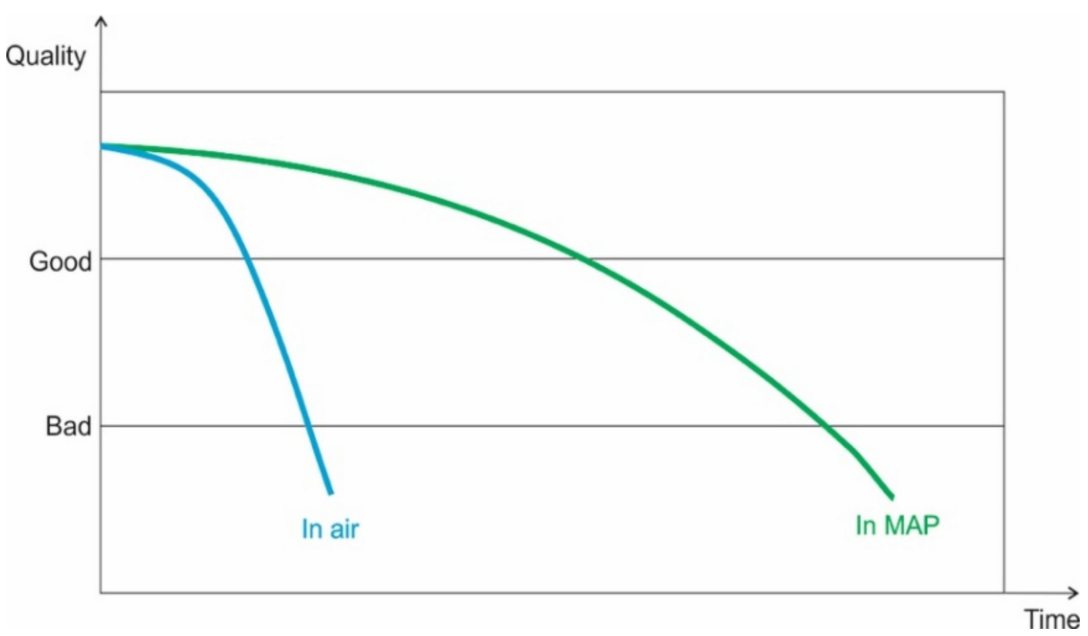

Figure 4. Loss of fish's taste and aspect quality in air and MAP, reprinted with permission from WITT Polska.

\subsection{Bakery Products Such as Cakes and Bread}

For products such as cakes, biscuits, bread or any other bakery products, the most detrimental occurrence is mold formation, which diametrically decreases their shelf-life. However, to minimize this risk, during the production and packaging process, it is really important to keep the highest standard of quality and cleanliness. Packages can be filled with MAP gas that includes $\mathrm{CO}_{2}$ with the smallest possible rest oxygen level to stop the development of mold and prolong the shelf-life at the same time (Figure 5). Like for any other products where $\mathrm{CO}_{2}$ reacts with food inside the package, here, nitrogen is also used as the filling gas to prevent the collapse of the package [5].

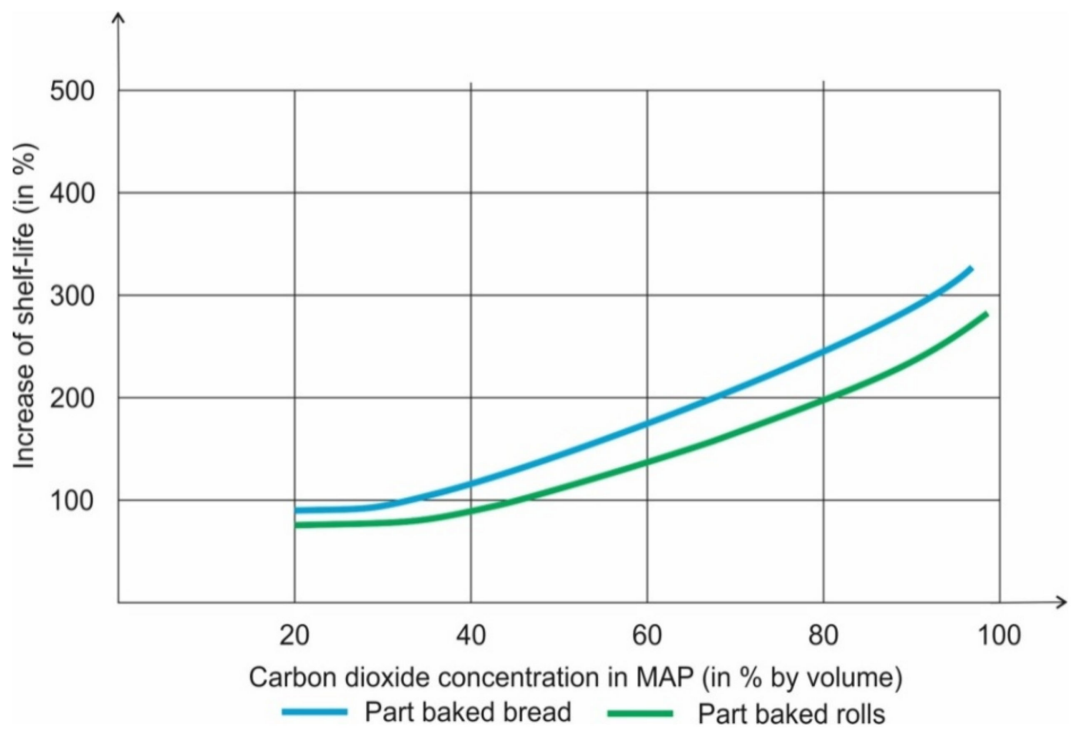

Figure 5. Increase in the shelf-life of a few types of bakery products with different levels of $\mathrm{CO}_{2}$ ratios in MAP, reprinted with permission from WITT Polska. 


\subsection{Agricultural Products including Vegetables and Fruits}

The gases included in MAP during the packaging process ensure that fresh and chemically untreated food can reach customers. Proper MAP-packed fresh vegetables and fruits have been compared to those without MAP [16,55-57]. The atmosphere generated by modified atmosphere packaging (MAP) delays the ripening of certain subtropical-tropical fruits, including mango or bananas, etc. [58]. Moreover, in vegetables and fruit such as cherries, low $\mathrm{O}_{2}$ levels generally inhibit the growth of most aerobic spoilage microorganisms, while the growth of anaerobic pathogens may be allowed or even stimulated; molds and Gram-negative aerobic bacteria are highly sensitive to $\mathrm{CO}_{2}[56]$ and require special treatment relative to the type of packaging and kind of atmospheres [12,21]. For example, in the case of tomatoes, it was proved that reduced levels of $\mathrm{O}_{2}$ or elevated levels of $\mathrm{CO}_{2}$ inside packages can reduce respiration and ethylene production rate, delay ripening, retard softening, and slow down various compositional changes associated with ripening [59]. The optimal concentrations of $\mathrm{CO}_{2}(5 \%)$ and of $\mathrm{O}_{2}(5 \%)$ delay the ripening of tomato [60]. The reason for this is-compared to any other food-vegetables and fruits still take in oxygen and even after harvesting, they have to have a high enough level of oxygen in their packaging [61]. For example, in potato strips, oxygen depletion causes the loss of product quality that would probably prevent consumers from eating the potentially hazardous foods [40]. That is why the film barrier has to be fit to each product separately [62]. Usually, thanks to micro-perforation, the concentration of carbon dioxide, nitrogen, and tiny levels of oxygen can ensure the breathability and the permeability of film as well [59]. The generally recommended percentage of $\mathrm{O}_{2}$ in a modified atmosphere for fruits and vegetables for both safety and quality falls between $1 \%$ and $5 \%$, although the oxygen level will realistically reach levels below $1 \%$ in MAP produce [9]. The name of this process is EMA (equilibrium-modified atmosphere) [17]. The ratio of gas concentration is individually defined to each product $[55,60]$. Anyway, it has been shown that MAP technology is able to extend the shelf-life of pomegranate whole fruit and arils. However, novel technologies such as 'smart' packaging offer the potential of further increases in the shelf-life and safety of MAP pomegranate whole fruit and arils [12].

Not only MAP gases but cleanliness and hygienic processes are fundamental issues that affect the long-lasting freshness of products [58,63]. Additionally, the use of unsuitable packaging materials can lead to technically unsuitable atmospheres with detrimental effects on product quality [64]. MAP is known to alter the microbial population of vegetables. Citrus fruits are an important source of bioactive compounds such as ascorbic acid, carotenoids, flavonoids, flavanone glycosides, and phenolic compounds; all of these are potentially health promoting. The use of plastic films to package citrus fruit can be beneficial in keeping them fresh during post-harvest storage. Nanoactive films, unlike other films available on the market, have the ability to retain more ethylene produced during fruit respiration. Films with an active layer of nanoporous-crystalline syndiotactic polystyrene (s-PS) extend the shelf-life of not only fruit. A longer shelf-life of products may be associated with a large increase and decrease in the concentration of carbon dioxide and oxygen inside the package, respectively [65-68].

In chilled MAP produce, this may result in the inhibition of the Gram-negative Pseudomonas spp., while encouraging the growth of Gram-positive lactic acid bacteria (LAB) [69]. If the MAP conditions are appropriate to the commodity, then microbial growth in general is reduced [70]. Thanks to MAP gases linked with the right cooling, it is very viable to have the prolonged shelf-life of food and make the perfect packaging design and great product freshness for the customer [22].

\subsection{Ready-Made Meals and Pasta}

Fresh pasta and especially ready-made meals significantly differ in composition and nature. The problem appears because products such as unfrozen sandwiches or pizzas can consist of many different ingredients which do not have identical dates of shelf-life, and thus, different spoilage parameters. In most cases, MAP gases where the level of $\mathrm{O}_{2}$ is 
minimal or almost nonexistent can highly prolong shelf-lives. So, usually, in the case of these products, $\mathrm{CO}_{2} / \mathrm{N}_{2}$ gas mixes are used. Furthermore, the share of gases is dependent on the composition in each product. An example would be a situation where food can absorb the high volume of $\mathrm{CO}_{2}$ and avoid the collapse of the package, so it would be required to use the nitrogen as the filling gas.

MAP technology can significantly extend the shelf-life of ready meals and other delicatessen preserved by quick cooling. It has been found that the use of $\mathrm{CO}_{2} / \mathrm{N}_{2}$ gas mixtures delays not only the microbial spoilage process but also the moment of the appearance of a rancid taste due to oxidation. The best gas to product ratio is 2:1 [7].

The main spoilage mechanism of fresh pasta is the growth of yeast and mold. In the case of fresh green pasta, it is a good idea to protect it from the effects of light to prevent discoloration. That is why they are commonly protected against the access of light by means of, for example, colored prints, pigmentation, or metallized foil. As with other products packed in a modified atmosphere, it is recommended to maintain appropriate storage temperatures and to follow the rules of hygiene and handling the product in order to reduce the risk of food poisoning. MAP technology can significantly extend the shelf-life of pasta. $\mathrm{CO}_{2} / \mathrm{N}_{2}$ mixtures are used to inhibit the growth of microorganisms and harmful oxidative reactions. The most commonly recommended gas to product ratio is 2:1 [6].

\subsection{Snacks Such as Chips and Nuts}

Products such as snacks including peanuts and potato crisps have one essential problem involved with fat contained in food. Most of the time, a risk of oxidation and food rancidity appears if, for example, the package is not tight enough [5]. Therefore, to prolong the shelf-life, a really important issue is to decrease the $\mathrm{O}_{2}$ rest to the minimum [71]. For example, very often, pure nitrogen is used as the MAP gas. Thanks to a solution such as this, it is much easier to prevent food from being affected by rancidity and spoiling as well as mechanical damage in the case of sensitive products, for example, delicate potato chips which have to be protected from crushing [7]. However, the kind of gas used definitely depends on the product; therefore, it is concluded that for storing fresh in hull pistachio nuts, modified atmosphere packaging with $100 \% \mathrm{CO}_{2}$ can be more beneficial and can extend the shelf-life of fresh in hull pistachios nut from 2 weeks to approximately 35 days [71]. The main cause of spoilage of dry foods with a high content of unsaturated fatty acids (breakfast cereals, muesli, potato chips, nuts, cocoa powder, and milk powder) is oxygen rancidity. This destructive process effectively inhibits packaging under $\mathrm{N}_{2}$ atmosphere. The most commonly recommended gas to product ratio is 2:1. Due to the very long shelf-life of dried products, which is obtained with the use of MAP technology, packaging materials must have a high barrier to moisture and gases. Metallized films have such properties. Certain dried foods, such as powdered infant formula, are particularly prone to aerobic rancidity, so residual $\mathrm{O}_{2}$ levels should not exceed $0.2 \%$. Very low residual $\mathrm{O}_{2}$ levels can be achieved by using $\mathrm{O}_{2}$ free radical scavengers in MAP packs.

\subsection{Wine and Drinks}

To keep the quality of wine products and protect the production process in different phases, usually, gases or MAP gas mixes are used. They have to be used to reduce the contact of the product with oxygen and avoid microbial aggravation. To reach these conditions, the headspace in the tank has to be filled by an inert gas or gas mixture, for example, a combination of gases such as $\mathrm{CO}_{2}, \mathrm{~N}_{2}$, and Ar. Of course, the concentration of each component gas is chosen depending on the kind of wine [7,72].

Liquid food and beverages are not packaged using conventional MAP equipment, and types of packaging typically used include cardboard containers, glass and plastic bottles, aluminum and steel cans, kegs, barrels, and stainless-steel tanks. $\mathrm{A} \mathrm{N}_{2}$ and /or $\mathrm{CO}_{2}$ purge is used with gaseous $\mathrm{N}_{2}$ and/or $\mathrm{CO}_{2}$ when bubbled through the liquid food and beverages to lower the dissolved $\mathrm{O}_{2}$ concentration. Such gas atomization is used commercially in the 
production of carbonated beverages, beers, lagers, mineral waters, fruit juices, etc., and can also be beneficial for other liquid food products.

\subsection{Coffee}

Because coffee as a dried product is quite resistant to spoilage by any microorganisms, it is relatively easy to store for a longer time. Wherein, the fatty acids which can cause oxidization may lead to rancidity as well. To avoid this process, the rest of the oxygen has to be reduced to a minimum in coffee packages. In capsules and sachets with coffee, very frequently, pure nitrogen gas is used [5]. It prevents any kind of microbial, enzymatic, and physical deterioration of the filled product, protects the product from insects, harmful bacteria and molds, and keeps it as fresh as it was on the first day of packaging. Furthermore, it is a proven technology that keeps the products fresh, preserves the aromas and color, helps to maintain natural structures, and extends shelf-life without using any chemicals.

\subsection{Dairy Products}

Dairy products such as cheese are usually spoiled by rancidness processes or increased numbers of microorganisms. For these products, it is really important to keep the cooling process uninterrupted, which certainly prolongs the shelf-life of them. In the case of hard cheese, the risk of mold formation can appear, especially during oxygen contact. Previously, vacuum packaging was used very often, despite some disadvantages such as being difficult to open and the existence of unattractive packaging traces [7]. Thanks to $\mathrm{CO}_{2}$, which does not influence the maturation of cheese, it is quite easy to effectively obviate mold formation. However, in case of soft cheese, the rancidity process can proceed relatively quickly. However, as before, a problem such as this can be solved quickly by using a MAP gas mix with $\mathrm{CO}_{2}$. However, a product such as soft cheese can absorb $\mathrm{CO}_{2}$ gas in a much bigger ratio, and also, here, the risk of package collapse can appear, which is mentioned in the previous chapter. A reaction such as this is caused by the use of lower levels of $\mathrm{CO}_{2}$ in the gas mix [72]. Products such as yoghurt, cream, and milk can absorb too much $\mathrm{CO}_{2}$, which causes the sour flavor of these products. Additionally, as in the case of soft cheese, a much lower $\mathrm{CO}_{2}$ level has to be chosen [5].

Milk powder is frequently used as baby food, so it has to be treated as a highly tender and sensitive product. To prolong the shelf-life of this product, it is particularly important to reduce or get rid of the $\mathrm{O}_{2}$ rest in the packaging. Generally, the packaging process of this product is carried out with the use of pure nitrogen to reach the minimal possible level of oxygen in the packaging [7].

\section{The Most Common Microbiological Contamination of Food}

According to the World Health Organization, dangerous food containing harmful bacteria can cause hundreds of different diseases. In 2016, European zoonosis monitoring activities were carried out. The most frequent ones were: campylobacteriosis, salmnellosis, yersiniosis, listeriosis, and (STEC) Shiga toxin produced by Escherichia Coli [70,73].

The components of protective gas atmospheres, especially $\mathrm{CO}_{2}$, have a significant impact on the development of microorganisms, which is graphically shown in Figure 6. Under anaerobic conditions of chilled storage with elevated levels of carbon dioxide, while slower-growing lactic acid bacteria are encouraged, the growth of aerobic spoilage microflora is discouraged. In the presence of oxygen, the growth of Brochothrix thermosphacta occurs and can cause the spoilage of meats. Most microorganisms require oxygen for growth, and due to its almost complete elimination in vacuum packaging, the growth of aerobic bacteria, molds, and yeasts is prevented under such conditions. This contributes significantly to the extension of the shelf-life of the packaged food and also allows for the preservation of sensory features that are appropriate and desired by consumers. However, it should be remembered that the quality and durability of vacuum-packed food depends to a large extent on whether it has been microbiologically re-contaminated before packaging, i.e., during technological processes [42]. 


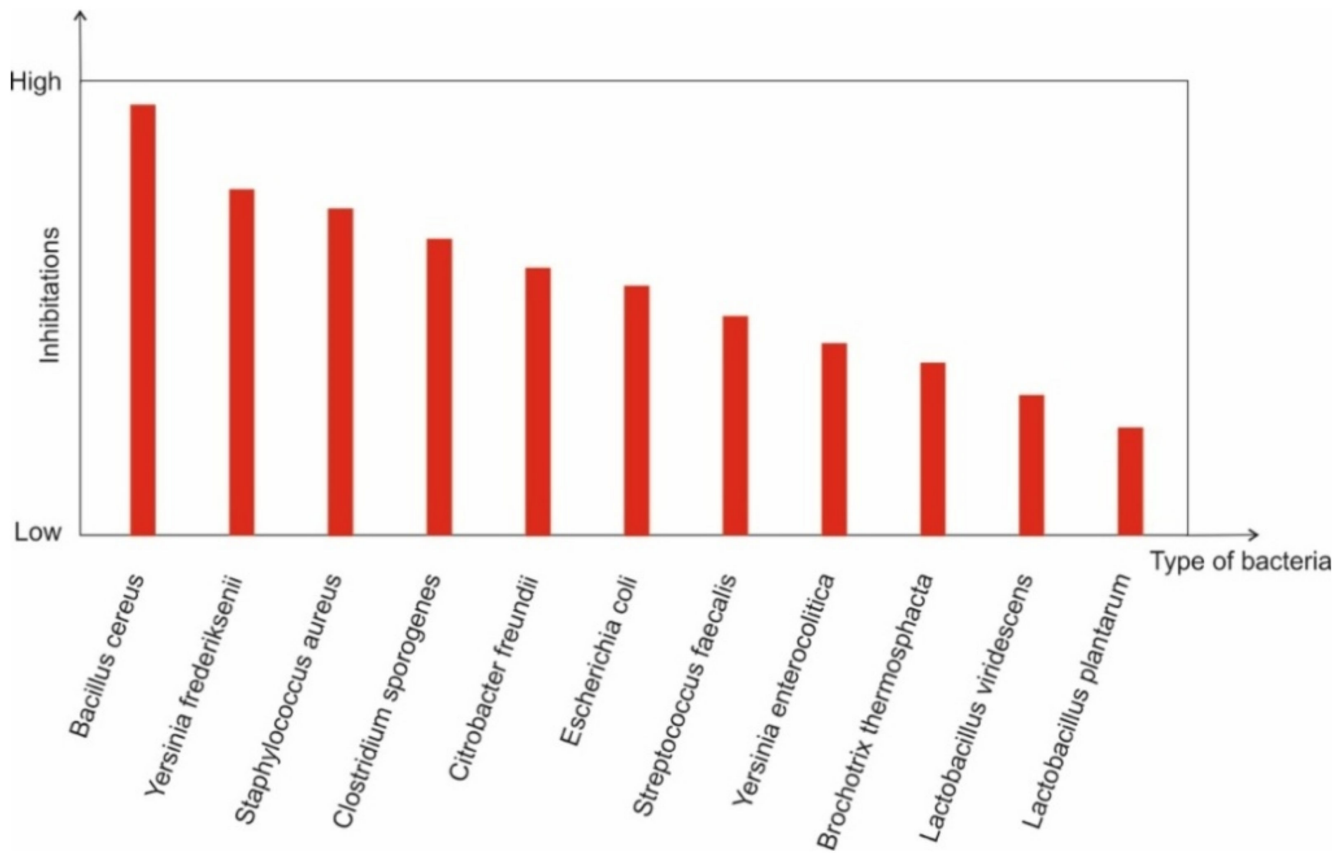

Figure 6. The influence of $\mathrm{CO}_{2}$ on various bacteria, reprinted with permission from WITT Polska.

Gas packaging as applied to some vegetables and meats could provide one option for controlling the surface contaminants of chilled carcasses, but the effect is usually to prevent the excessive growth of genera such as Pseudomonas or Salmonella rather than their eradication $[43,74]$.

Bacteria are the most common pathogenic agent. It is estimated that salomenella accounts for $50 \%$ of nutritional diseases caused by bacterial factors [53]. The main food products that are the source of infections are eggs, poultry, fish, crustaceans, mollusks, poultry, meat products, and, other than milk, dairy products [74]. The value of food matters to food producers as well as to distributors and consumers. In some cases, food may be improperly processed or contaminated with spoilage bacteria. It depends on the type of products storage, time, and processing degree [75]. Consumers' demand for fresh and healthy food means that the food industry is looking for technologies that will ensure higher food quality, ensure safety, and reduce the risk of food contamination with bacterial pathogens. New processing technologies, in particular food storage, can be a tool to improve the value of food [76].

Salmonella spp. is one of the causes of diseases transmitted by food pathogens [77]. It is usually related to food of animal origin: chicken, red meat, and pork. Food contamination with salmonella may occur during the production or inappropriate handling of food. Salmonella contaminants cause losses during food production and the withdrawal of products from production or sale [78,79].

Campylobacter spp. causes serious food poisoning. It is estimated that more than $50 \%$ of the diseases that this pathogen corresponds to are attributed to poultry products such as chicken burgers and nuggets. Campylobacteriosis is a disease so serious that in New Zealand, since 1980, is a disease that needs to be reported [80].

E. coli O157: H7 was identified in 1982 and is now considered a dangerous food pathogen.

Bacillus cereus belongs to the bacterial family of one of the most troublesome food pathogens. Bacillus-resistant endospores are troublesome for food producers. Mainly, handling raw food or cooking food is their source. Often, Bacillus cereus is the cause of food poisoning because their spores can withstand high cooking temperatures [81]. Bacillus cereus is a large Gram-positive, mobile, aerobically active pathogen. Oxygen allows for the easy sporulation of bacterial spores [82].

Studies with the help of a transmission electron microscope have shown that the cells have a cytoplasmic membrane surrounding the cell contents. Some strains contain a surface 
protein (S layer). The inner membrane, the bark, and the inner and outer mantle surround the spore core. Bacillus cereus spores do not have metabolic activity; therefore, they are resistant to heat, frost, drying, and radiation. All these features are defensive factors of bacteria $[83,84]$. Bacillus bacteria are widespread in the environment. Several species of Bacillus are related physiologically, genotypically, and phenotypically with Bacillus cereus.

Bacillus cereus is a large group, which includes many species, such as $B$. thuringiensis, B. mycoides, B. anthracis, B. pseudomycoides, and B. weihenstephanensis.

For most species, soil is a natural environment. Soil agricultural products can be contaminated by many species. This causes food contamination and spoilage. However, the most important species that significantly affect the spoilage of food is B. cereus [85].

Bacillus cereus is characterized by resistance to endospores and their long-lasting ability to survive. It easily transitions from the natural environment to dissimilar types of food, especially cereals and its derivatives, rice, vegetables, herbs, dairy products, milk, raw meat, eggs, and ready-to-eat foods [84,86-88].

Bacillus cereus produces three different enterotoxins and emetic toxins (ETEs): nonhemolytic enterotoxin (Nhe), BL hemolysin $(\mathrm{Hbl})$, and cytotoxin $\mathrm{K}(\mathrm{CytK})$. $\mathrm{Hbl}$ and Nhe consist of three different proteins: L1, L2, and B and NheA, NheB, and NheC. CytK is a one-component toxin $[81,89,90]$. B. cereus can be found in meat seasonings as well as meat products subjected to heat treatment. In this case, these bacteria are a threat because they are resistant to heat stress. The pathogen can also occur in frozen meat semi-finished products. B. cereus can also be found in raw milk, in which it is present as a spore capable of surviving the pasteurization process [91]. Other products such as spices, baby food, seafood, chocolate, legumes, cereals, cereal products, and fresh vegetables may contain B. cereus $[92,93]$.

B.cereus spores can adhere to hydrophobic surfaces, which is a threat to the food industry. The small spore surface and high hydrophobicity cause strong adhesion [81].

Salmonella is an anaerobic bacterium. It is a pathogen that can often be found in food. The occurrence of salmonellosis occurs in fresh fruit and vegetables: apples, mango, lettuce, tomatoes, melon, and celery [53,94,95].

Food poisoning with staphylococcus (SFP) is a very common occurrence worldwide. SFP is caused by the intake of one or several staphylococcal enterotoxins during organza growth in food [96]. Staphylococcal enterotoxins show endurance in the face of stressful situations. Enterotoxins are resistant to proteolytic enzymes and are very stable in digestive tracts, such as trypsin and pepsin. They are therefore active in the digestive system [97].

\section{Modern and Safe Food Systems for Polymer Packaging}

Active packaging, sometimes referred to as interactive or "smart" packaging, is intended to sense internal or external environmental changes and to respond by changing its own properties or attributes and hence the internal package environment [98].

Active packaging functions and technologies include moisture control, $\mathrm{O}_{2}$-permeable films, $\mathrm{O}_{2}$ scavengers or absorbers, $\mathrm{O}_{2}$ generators, $\mathrm{CO}_{2}$ controllers, odor controllers, flavor enhancement, ethylene removal, antimicrobial agents, and microwave susceptors [99,100] in addition to indicators of specific compounds and temperature control packaging.

Intelligent systems are designed to provide better product quality and safety. Very often, these systems occur in the form of intelligent etiquettes placed on the packaging. Temperature indicators are also used for products sensitive to low temperatures. The indicator allows you to obtain information regarding whether the product has been frozen or exposed to low temperatures. The indicator is built in the form of a tube that contains a liquid that, after exceeding the temperature limit after $30 \mathrm{~min}$, turns violet. There are four types of this indicator available in the industry depending on the set limit temperature: $-3,0,2$, and $5{ }^{\circ} \mathrm{C}$. A small device was also created-a plotter used as a small recorder to store the history of temperature from production to transport. It can reveal all temperature overflows, which is very useful in the case of drug transport. It operates in a temperature 
range from -40 to $+85^{\circ} \mathrm{C}$ with a precision of $0.5^{\circ} \mathrm{C}$. The plotter is a small and powerful device that allows for easy placement in the desired place [101].

Antimicrobial packaging is an extremely challenging technology that could extend shelf-lives and improve food safety in both synthetic polymers and edible films. An interesting alternative to polymer packaging is hybrid packaging. They combine the advantages of organic components with inorganic components. This ensures the creation of packages with interesting new features. They have permission to obtain monoliths, gels, powders, and even fibers. Organic-inorganic hybrids are characterized by plasticity, the ability of easy processing, and thermal and chemical resistance. Polymeric nanocomposites can be distinguished in the material group. These are two-phase systems in which the polymer matrix is reinforced with fillers such as nanotubes and layer silicates that are mechanically and thermally resistant. It is possible to obtain polymeric nanocomposites in the form of foils, containers, and coatings. Currently, intensive research focuses on the creation of active packaging based on biodegradable polymer perocomposites that could come from renewable raw materials. Naturally, polymers such as chitosan, cellulose, starch, and gelatin are cheap, available, and easily compostable. Hybrid systems based on biopolymers and inorganic polymers are becoming more popular. One of these combinations is gelatine-siloxane material. The meadow material obtained in this way has the features of biodegradable gelatin and mechanical and thermal resistance as well as the hydrophobicity characteristic of organosilicon compounds [13].

Ensuring the quality of food and safety is one of the greatest challenges of the present food industry. The microbiological contamination of food has led to the search for solutions to stop the numbers of microorganisms in food. New-generation packaging is a challenge for the current market. Progress to improve the physical, chemical, sensory, and microbiological protection of food to improve shelf-life and to reduce FLW include new technologies, such as nanotechnology and active packaging [18]. Packaging technologies should prolong food shelf-life. The application of antibacterial polymers in food packaging can help to solve these problems $[102,103]$. Furthermore, the gas and water barrier properties of the investigated biobased packaging materials are sufficient to achieve the same shelf-life as that achieved by conventional packaging [38].

Antimicrobial solutions may take the form of:

- Sachets with volatile antimicrobial agents,

- Antimicrobial agents of volatile and non-volatile used into polymers,

- Antimicrobials adsorbed on the polymer,

- Immobilization with ionic or covalent bonds to polymers,

- The use of anti-bacterial polymers.

To summarize the above, active packaging is a technology developing a new trust because of recent advances in packaging, material science and new consumer demands [104].

All of these technologies can lead to the achievement of ever-longer shelf-lives for food, meaning it is really important to develop them in the future, but on the other hand, this must be done with the highest care for the environment. Packaging has to be made in a sustainable manner because future packaging developments should focus on further advancements in packaging technology but should not neglect the importance of indirect effects of packaging [41].

\section{Edible Chitosan Coatings in Processed Foods}

The introduction of modern packaging methods includes the development of optimal inert gas MAP atmospheric composition for fresh produce; bioactive polymeric films with antimicrobial activity against foodborne pathogens via the immobilization of bacterial cells or antimicrobials on polymers; the incorporation and controlled release of volatile and non-volatile antimicrobial agents into packages; and the use of biopolymers that are inherently antimicrobial [55].

One natural biopolymer that exhibits antibacterial and antioxidant properties is chitosan. It is shown to be compatible with other biopolymers and lipids. Due to its features, 
it is possible to formulate different foils adapted to specific purposes. It can create shells with improved functionality and performance $[2,105,106]$. Chitosan is a natural polysaccharide from which biodegradable films and coatings are formed. It is obtained by the $\mathrm{N}$-deacetylation of chitin (poly- $\beta-(1,4)-\mathrm{N}$-acetyl-d-glucosamine), which is the main component of the shells of insects and crustaceans. It can also be obtained in seafood waste (from shells, crabs, shrimps, and lobsters) through the use of alkaline solutions and high temperatures. Chitosan is a non-toxic hydrocolloid with biocompatible and biodegradable properties. Unlike other hydrocolloids, it is positively charged [107-109]. Amine chitosan groups that react with the cell wall have antimicrobial and antifungal activity. As a result, cell wall permeability and cell extinction changes. The degree of deacetylation of chitosan affects its antimicrobial effect. Higher antibacterial performance depends on a higher degree of deacetylation.

Other external agents, such as, for example, the type of medium, temperature, and $\mathrm{pH}$ factor, also affect the activity. It has been found that the anti-bacterial effect of chitosan is greater in the case of Gram-positive bacteria compared to Gram-negative [108,109]. Films based on fish gelatin and chitosan are colorless and transparent, but they exhibit excellent barrier properties against UV light. In addition to light barrier properties, appropriately formulated films and coatings should meet those aspects related to oxygen barrier to control oxygen exchange between food and the surrounding atmosphere, protecting food and delaying its deterioration by discoloration or texture softening [54]. The combination of chitosan with other biopolymers improves the film's properties that are a barrier to water. For this purpose, pectin or corn starch is added to the laminated chitosan foil. Chitosan coatings have been shown to work against fungi, yeasts, and bacteria. Furthermore, this activity in the antimicrobial sphere can be increased by the addition of appropriate polysaccharides [110].

Chitosan coatings have a special antimicrobial effect by acting on Escherichia coli and Staphylococcus aureus. The increase in the effect of chitosan can also be increased by adding peptides, metals, or essential oils to the polymer structure. The use of silver nanoparticles to chitosan and starch has shown bactericidal activity against Staphylococcus aureus, Escherichia coli, and Bacillus cereus. Even better effects were obtained by adding zinc oxide to silver nanoparticles [111-113]. Films created based on chitosan and additional antimicrobials and antioxidants have been used to extend the period of 'foodiness' for the consumption of fish and meat products [114]. Such products are easily subject to microbiological destruction and the oxidation of lipids. Such chitosan coatings act against Listeria monocytogenes. Chitosan coatings are used to extend the shelf-life of freshly cut or low-processed fruit or vegetables. The potential of chitosan coatings is confirmed by scientific research. Thanks to research, we know that food that may or may not interact with the adjoining packaging materials. In result, this might change the initial mechanical and barrier properties of the materials, as well as the safety of the product at consumption [15]. Chitosan can be added into recycled products such as multi-layer film packaging materials, where every polymer coating performs a specific function. It can act as an antioxidant, an antimicrobial or a water insulator. A major challenge is the production of chitosan coatings that could further reduce production costs. For this purpose, it seems appropriate to combine chitosan with biodegradable ingredients that can form thermoplastic films [98]. This effect can be obtained by using some proteins or starch [106].

\section{Forms of Quality Control in MAP Packaging}

The correct concentration of gas mix inside packaging, or just the right gas, is only one of a few aspects which can ensure correct conditions inside the packages and the correct packaging process. To be sure that, there are no errors or any damage in any point of the process, the operator has to check the final result of the packaging process, which is the finished package. The random inspection of finished packaging is visible in Figure 7-it is a destructive test. In terms of the final results, it means the concentration of gas mix or the correctness of the gas used. Of course, it is always the market that does not 
like vacuum packaging, and it is easy to measure gas mix concentration in the industry condition via a special tool called a gas analyzer. Thanks to this device, operator or quality department officers can compare the concentration of gas mix in the inlet and outlet of the packaging process in a really fast and easy way. When we obtain the same gas mix in the sample testing packages which led to the packaging machine, it means that there were probably no damage or errors in the packaging process. We can mark out three methods of measurement via gas analyzer which we can use on sample packages. The first method is called sample mode, where a gas analyzer, via a small needle, punctures the sample, and after a few seconds, we receive the reliable and fast result of the measurement. In the case of the food industry, usually, the MAP gas mixture contains $\mathrm{CO}_{2}$ and $\mathrm{O}_{2}$, and that is why the analyzers available on the market are able to measure these components of MAP gas mix. In most cases, infrared cards have been used to measure the $\mathrm{CO}_{2}$ in gas and were characterized by quite a low price and suitable measurement accuracy. To measure the $\mathrm{O}_{2}$ concentration, the most popular methods are electrochemical sensors which work like a battery and have to be replaced every 1-2 years for a new one; fortunately, they are quite cheap. Another way to check the concentration of $\mathrm{O}_{2}$ is by using paramagnetic or zirconium sensors, which may have better accuracy and have other advantages but are more expensive compared to electrochemical sensors. On the market, it is possible to find many different models of gas analyzers, but one of the best ones produced by a company with many years of experience in the field of gas measurements is an analyzer named Oxybaby - the product of Witt Gasetechnik Company located in Witten in Germany. The biggest advantage of this device is that we can use it directly on the production line with one-handed operation because it is a mobile tool with low weight and battery power supply. Furthermore, the measurement results can be stored on a micro-SD card and can next be used to create a quality report or kept for future from auditors' use. Using sample methods of measurements, it is much easier to find any incompatibilities in the production process and react quickly so that inconsistent products are not on the market. The manufacturer gains confidence that their products meet the highest quality and only reliable and tested products reach the customers. Nowadays, it is almost impossible to produce products in the food industry without the correct procedure of gas mix analysis and without reliable tools such as gas analyzer devices. Of course, we have to remember that this kind of measurement via a needle is a destructive kind of measurement (Figure 7a) and after the test, the package cannot go back to the production line and has to be repacked.

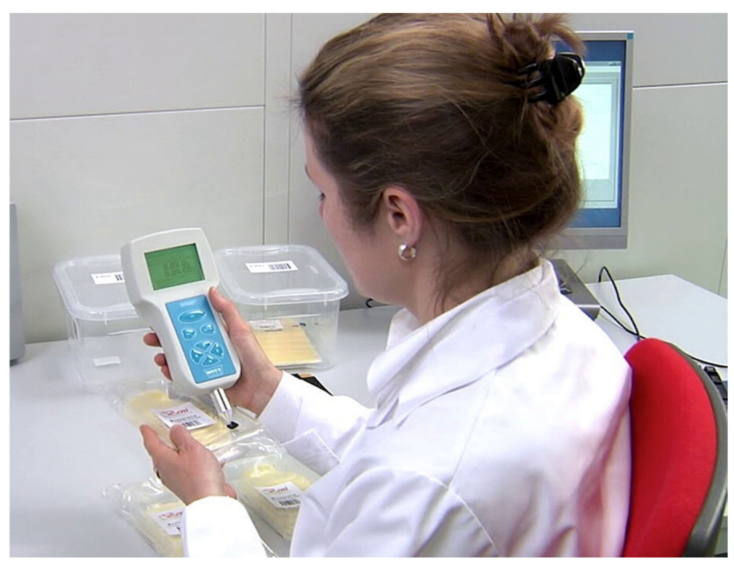

(a)

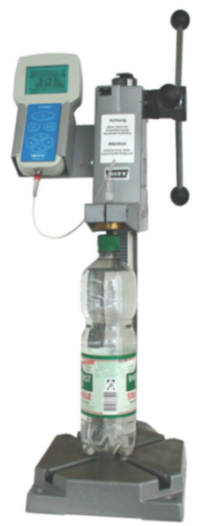

(b)

Figure 7. Random needle control. Sample mode analyzer, Oxybaby ${ }^{\circledR \circledR}{ }^{\circledR}:$ (a) container control, (b) bottle control, reprinted with permission from WITT Polska.

There is also a possibility, with use of an analyzer such as this one above, to make sample measurements in overpressure samples such as bottles of sparkling water or cans (Figure $7 \mathrm{~b}$ ). To do this specific test, special equipment is required, which is a special stand 
that keeps the bottle in a vertical position, and it is pierced via a special bold needle. Thanks to this equipment, it is possible to check the rest of the $\mathrm{O}_{2}$ or $\mathrm{CO}_{2}$ concentration.

Another measurement method is checking of the continuous gas mix via a lance or overpressure inlet. This method is used in the most cases with connection with packaging machines and directly ensures the measurement of the gas mix before packaging machines or devices such as vacuum machines are used or measurement gas mixes are added in the process for a device such as a flow pack machine. The difference between sample mode and continuous mode is caused by the use of a different type of analyzer. In the sample mode, we use a mobile analyzer; for the continuous method, we can only use table devices which are not so mobile but have any other advantages, such as the possibility to use more types of $\mathrm{O}_{2}$ sensors such as zirconium and paramagnetic sensors which are characterized by better accuracy and longer lifetimes. Despite this, these devices will be able to be equipped more readily in the future, such as in fully automatic calibration or special relays which can be switched when set limits are exceeded. Analyzers such as, for example, PA $7^{\circledR}$ (Figure 8) can be connected with packaging machines to stop production in the case of any damage or when the concentration of gas mix reaches unacceptable values. An opportunity like this provides a very high level of quality and ensures that every product which goes out from the line is preserved by the unique and correct MAP gas.

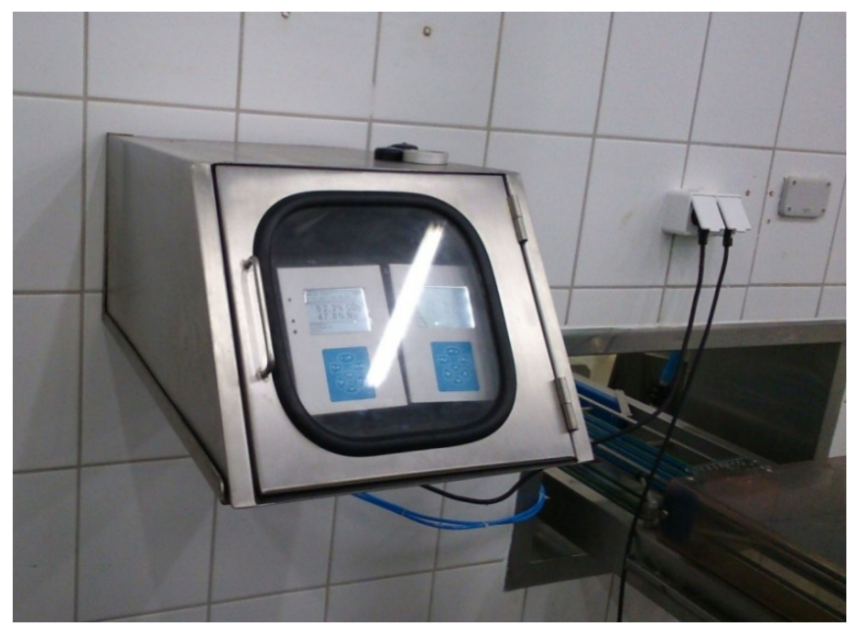

Figure 8. Continuous mode analyzer $P A 7^{\circledR}$, reprinted with permission from WITT Polska.

The actual state of the art in the food industry and gas measurement technology ensures an even more advanced method of checking concentration where the measurement is non-destructive. In this type of measuring method, a laser beam is used (Figure 9). The measurement principle is based on counting the times the laser beam passes through the package containing gas such as $\mathrm{O}_{2}$ or $\mathrm{CO}_{2}$. Unfortunately, despite many advantages, this method also has a disadvantage and can be used only with transparent packages and should contain the right amount of MAP gas. An example of a device like this is Oxybeam ${ }^{\circledR}$, which was produced by Witt Gasetechnik, a company from Germany which is the leader and trends setter in terms of MAP gas measurement.

The next step in quality control to ensure fresh product is perfect packaging in packaging control and leak detection in packages. Only tight "packs" can protect products inside packages such as film packs, bags, bottles, sachets, or any other component for a long time. Furthermore, if a packaging system contains defects, channels can be created in the packaging, and microorganisms can ingress through the channels, affecting the safety of the product [38]. 


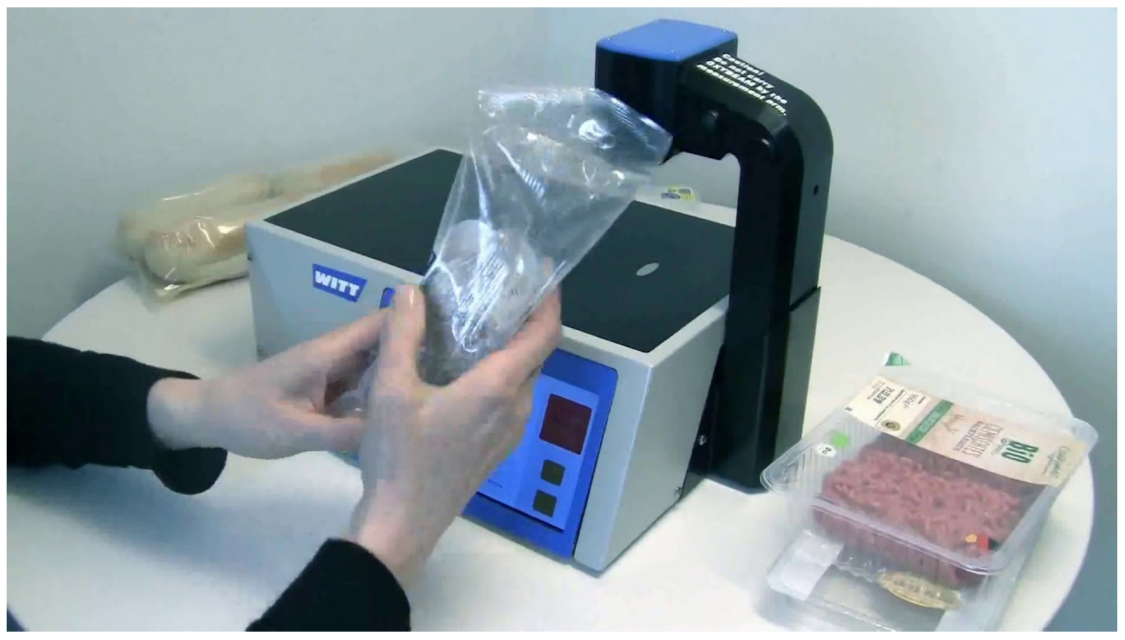

Figure 9. Non-destructive method of $\mathrm{O}_{2}$ or $\mathrm{CO}_{2}$ measurement by Oxybeam ${ }^{\circledR \circledR}$ analyzer, reprinted with permission from WITT Polska.

If packaging and components leak, the consequences can be fatal, so a simple way of eliminating this risk is to use a water bath to detect every leak and to find out where every leak originates from, if they exist. A system like this enables the detection of even the smallest of leaks in any products, packaging, and packs. The testing products can be food items (even without MAP gas mix or vacuum products), electronic items such as lights for automotive, pharmaceutical products, bubble wrap, bottles (including glass products), or any other packs created from PET. With this device, it is possible to test the vacuum packages, which was mentioned previously. The principle of operation is extremely simple and cost-effective: the test pack has to be inserted into a chamber which is filled with water. This is shown in Figures 10 and 11. The compressed air connected to this device pushes air out from the space over the water level to evacuate it from the device. In the points where leaks exist, the under pressure causes the escape of air or filling gas, which leaves the package toward to lid of the testing chamber, visible in the form of air bubbles.

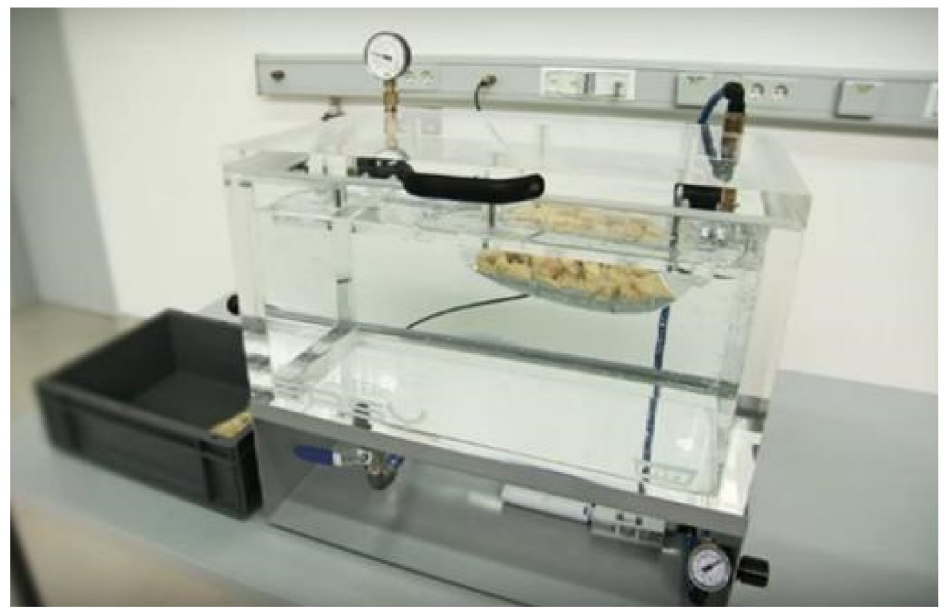

Figure 10. Leak detection by Leak Master Easy ${ }^{\circledR \circledR}{ }^{\circledR}$ device, reprinted with permission from WITT Polska.

One of the biggest advantages of the leak detection system is the possibility to checkif there are any leaks, and if where they are, in a quick and easy way. An advantage like this is really important, especially for technologists, because it provides a very fast reaction and makes it possible to make changes in the production process in the case of any abnormality. What is important is that on the market, it is easy to find the right-sized chamber to compare the dimensions of the sample being tested. The system can be equipped in an 
electronic control module where all results of measurements can be stored and kept for future quality reports or just for production and auditors' use, which is the same as in the case of analyzers.

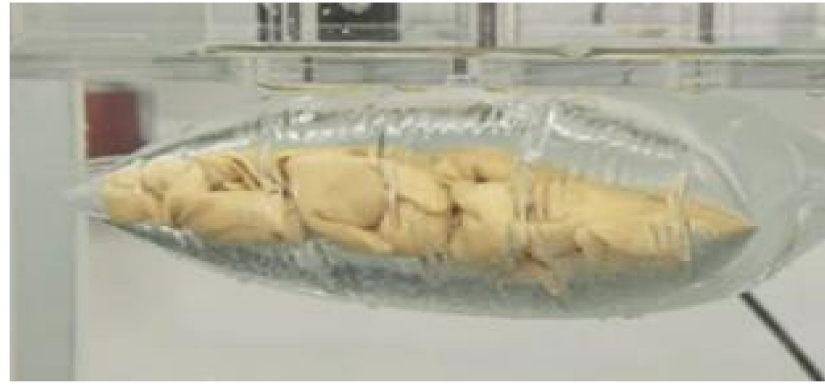

(a)

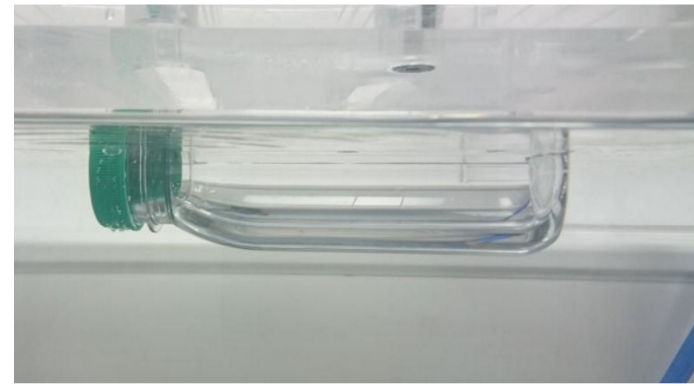

(b)

Figure 11. Leak detection in a bag/pouch (a) and bottle (b), reprinted with permission from WITT Polska.

"Industry 4.0" assumptions assume automatic, continuous, and complete data exchange between individual cooperating systems; therefore, companies wishing to find themselves in the era of total digitalization and competing with the world's largest brands must introduce extremely technologically advanced devices and processes that guarantee that existing cyber-physical systems can control physical processes and create a digital copy of the real world for real-time communication between themselves and people.

To meet the above requirements, one company has created an extremely modern device that controls $100 \%$ of packaging production in terms of its tightness, with the accuracy of leak detection up to $0.02 \mathrm{~mm}$. The device created under the name Leak Master MAPMAX (WITT-Gasetechnik GmbH \& Co KG, Witten, Germany) (Figures 12 and 13) is implemented directly in the production line right after the packaging machine so that each of the manufactured parcels is tested, and the product coming down from the production line meets the requirements of the highest quality standards. Furthermore, this device fully meets the objectives of "Industry 4.0" through continuous product control and the archival of measurement data, which are then passed to the server of quality results, which both in real-time and in the historical crack not only testify to the correctness of the production process but help to improve this process [7].
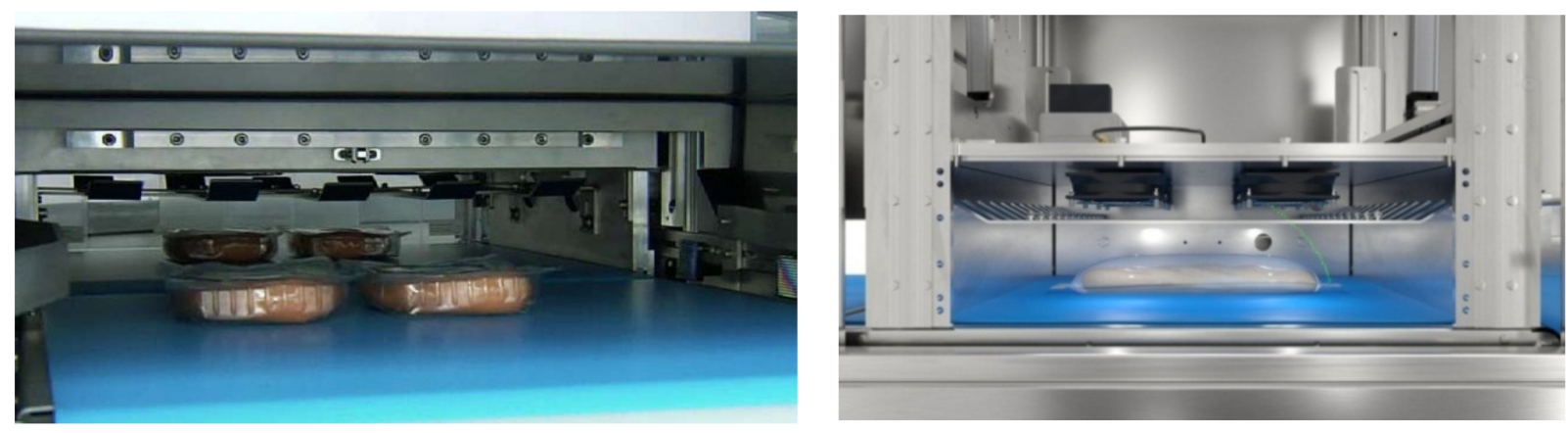

Figure 12. $100 \%$, non-destructive control of packaging tightness in-line device Leak Master MAPMAX ${ }^{\circledR \circledR}$ (interior), reprinted with permission from WITT Polska.

Going further towards the assumptions and requirements of the current technological revolution, the device has implemented an extremely advanced algorithm that makes almost a real-time decision about the correctness, or lack thereof, of packing of a particular package. It ultimately translates into an intelligent decision to leave a given package on the production line or to remove it as a defective product [7]. 


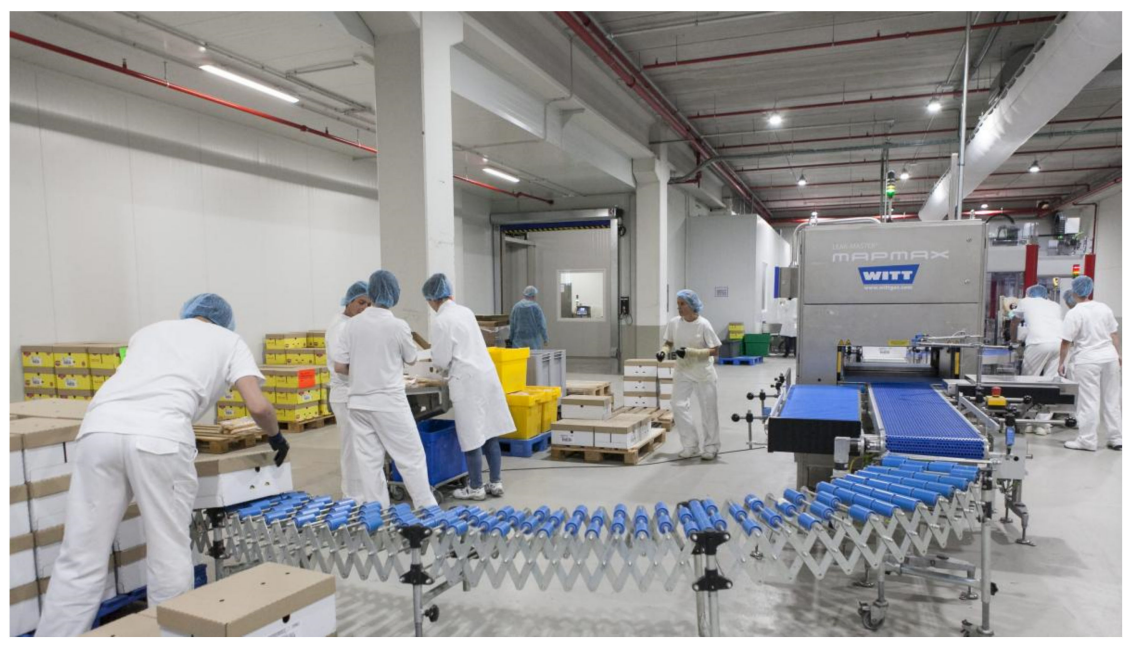

Figure 13. Non-destructive $100 \%$ control of packaging tightness, in-line device Leak Master MAPMAX ${ }^{\circledR}$, reprinted with permission from WITT Polska.

Thanks to the use of this device, the manufacturer can not only control the tightness of individual packages, but also can make sure that their product is of the highest quality and will not lose even a part of its value through the inappropriate atmosphere surrounding the product, which may occur in the event of leakage of the packaging, and which this is intended as a barrier between the assumed protective atmosphere inside and what is outside the packaging [36]. As can be read in any other publication, future development work focused on an automated $100 \%$ on-line non-destructive leak tester, especially for vacuum packages, would certainly be of interest to the food industry. Leak testing of vacuum packages requires the highest possible sensitivity, since only minor amounts of tracer gas can be added in vacuum packages [37].

\section{Summary}

Food packaging and packaging systems are developing dynamically, which is contributed to by global trade and growing requirements as to the quality and shelf-life of products. Most food products are perishable and perish very quickly, which results in the use of complex, multi-layer packaging and modern control systems. Food packaging very quickly becomes a nuisance waste; therefore, techniques should be developed to minimize product losses, which will allow a reduction in the amount of packaging used.

In terms of food packaging, one of the very attractive directions of study is the use of polymer films and MAP protective gas atmospheres. MAP packaging requires specific control methods. Traditional methods are random and require the destruction of the packaging. The product is lost or needs to be repackaged, resulting in food and polymer wastage. Modern methods for the non-invasive control of $100 \%$ of products on the technological line are more and more often used. These are advanced techniques that require investment outlays, but large, modern industry, especially integrated with Industry 4.0 , is where they find their place.

The use of appropriate gas mixtures in combination with modern control methods and maintaining cooling conditions throughout the supply chain allows for measurable shelf-life elongation. Thanks to this, product losses in trade are significantly reduced and at the same time, food waste by final consumers is reduced. Therefore, packaging innovations can reduce the environmental impact of food and polymer waste by prolonging shelf-life and reducing waste amounts along the distribution chain and at the household level.

Another important direction for research is the development of intelligent packaging. By monitoring the condition and quality of the packaged product and the ability to communicate with the consumer (or their smartphone), it is also an important source of reducing product losses, and thus the number of packages. Nevertheless, smart packaging 
often requires advanced materials and sometimes even a flexible screen or power supply, which can be ecologically troublesome.

Author Contributions: Conceptualization: T.R., K.C. and V.K.T.; investigation/literature review: K.C., J.W.-K. and T.R.; writing - original draft preparation K.C., J.W.-K. and T.R.; writing-review and editing: T.R. and V.K.T.; supervision: T.R. All authors have read and agreed to the published version of the manuscript.

Funding: This research received no external funding.

Institutional Review Board Statement: Not applicable.

Informed Consent Statement: Not applicable.

Data Availability Statement: Not applicable.

Conflicts of Interest: The authors declare no conflict of interest.

\section{References}

1. Castellanos, D.A.; Herrera, A.O. Modified Atmosphere Packaging: Design and Optimization Strategies for Fresh Produce. In Postharvest Handling; Kahramanoglu, I., Ed.; InTech: Nappanee, IN, USA, 2017; ISBN 978-953-51-3533-3.

2. Han, J.-W.; Ruiz-Garcia, L.; Qian, J.-P.; Yang, X.-T. Food packaging: A comprehensive review and future trends. Compr. Rev. Food Sci. Food Saf. 2018, 17, 860-877. [CrossRef]

3. Ketelsen, M.; Janssen, M.; Hamm, U. Consumers' response to environmentally-friendly food packaging-A systematic review. J. Clean. Prod. 2020, 254, 120123. [CrossRef]

4. Czarnecka-Komorowska, D.; Wiszumirska, K. Sustainability design of plastic packaging for the Circular Economy. Polimery 2020, 65, 8-17. [CrossRef]

5. Published and Unpublished Linde Gas Materials. Available online: https://www.linde-gas.com/en/processes/index.html (accessed on 18 October 2021).

6. Cousté, N.L.; Martos-Partal, M.; Martínez-Ros, E. The power of a package: Product claims drive purchase decisions. JAR 2012, 52, 364-375. [CrossRef]

7. Published and Unpublished Witt-Gasetechnik Materials. WITT-Gasetechnik GmbH \& Co KG, Witten, Germany. Available online: https:/ / www.wittgas.com/ (accessed on 18 October 2021).

8. Witt Gasetechnik How Modified Atmosphere Packaging Extends the Shelf Life of Food Products. Available online: https: //www.wittgas.com/consulting-service/white-papers/modified-atmosphere-packaging.html (accessed on 7 October 2021).

9. Singh, S. Modified atmosphere packaging of fresh produce: Current status and future needs. LWT-Food Sci. Technol. 2010, 3, 381-392. [CrossRef]

10. Ben-Yehoshua, S.; Beaudry, R.M.; Fishman, S.; Jayanty, S.; Mir, N. Modified Atmosphere Packaging and Controlled Atmosphere Storage. In Environmentally Friendly Technologies for Agricultural Produce Quality; Taylor \& Francis Group: Abingdon, UK, 2005; pp. 62-102.

11. Floros, J.D.; Matsos, K.I. Introduction to Modified Atmosphere Packaging. In Innovations in Food Packaging; Elsevier: Amsterdam, The Netherlands, 2005; pp. 159-172. ISBN 978-0-12-311632-1.

12. Caleb, O.J.; Opara, U.L.; Witthuhn, C.R. Modified atmosphere packaging of pomegranate fruit and arils: A Review. Food Bioprocess Technol. 2012, 5, 15-30. [CrossRef]

13. McMillin, K.W. Where is MAP going? A review and future potential of modified atmosphere packaging for meat. Meat Sci. 2008, 80, 43-65. [CrossRef]

14. Lawlor, K.A.; Pierson, M.D.; Hackney, C.R.; Claus, J.R.; Marcy, J.E. Nonproteolytic clostridium botulinum toxigenesis in cooked turkey stored under modified atmospheres. J. Food Prot. 2000, 63, 1511-1516. [CrossRef] [PubMed]

15. Gavriil, G.; Kanavouras, A.; Coutelieris, F.A. Food-packaging migration models: A critical discussion. Crit. Rev. Food Sci. Nutr. 2018, 58, 2262-2272. [CrossRef] [PubMed]

16. Rydzkowski, T.; Michalska-Pożoga, I. Wpływ pakowania w atmosferze modyfikowanej na jakość sensoryczna pieczarek przechowywanych w warunkach chłodniczych. Postępy Tech. Przetwórstwa Spożywczego 2013, nr 1, 69-74. (In Polish)

17. Singh, R.; Giri, S.K.; Kotwaliwale, N. Shelf-life enhancement of green bell pepper (Capsicum annuum L.) under active modified atmosphere storage. Food Packag. Shelf Life 2014, 1, 101-112. [CrossRef]

18. Wikström, F.; Verghese, K.; Auras, R.; Olsson, A.; Williams, H.; Wever, R.; Grönman, K.; Kvalvåg Pettersen, M.; Møller, H.; Soukka, R. Packaging strategies that save food: A research agenda for 2030. J. Ind. Ecol. 2019, 23, 532-540. [CrossRef]

19. Nigusu, W. Role of Food Packaging on Minimizing Food Losses and Waste and Securing Food System. Available online: https://www.academia.edu/10359504/ROLE_OF_FOOD_PACKAGING_ON_MINIMIZING_FOOD_LOSSES_AND_ WASTE_AND_SECURING_FOOD_SYSTEM (accessed on 18 October 2021).

20. Hyun, J.-E.; Lee, S.-Y. Effect of modified atmosphere packaging on preserving various types of fresh produce. J. Food Saf. 2017, 38, e12376. [CrossRef] 
21. Waghmare, R.B.; Annapure, U.S. Combined effect of chemical treatment and/or modified atmosphere packaging (MAP) on quality of fresh-cut papaya. Postharvest Biol. Technol. 2013, 85, 147-153. [CrossRef]

22. Mangaraj, S.; Goswami, T.K. Modified atmosphere packaging of fruits and vegetables for extending shelf-life-A review. Fresh Prod. 2009, 2, 1-31.

23. Balkir, P.; Esmer, O.; Irkin, R. The effect of modified atmosphere and vacuum packaging on the physicochemical, microbiological, sensory and textural properties of Crottin de Chavignol Cheese. Meat Sci. Food Sci. Technol. Res. 2011, 88, 221-226. [CrossRef]

24. Guo, Y.; Gao, Z.; Li, L.; Wang, Y.; Zhao, H.; Hu, M.; Li, M.; Zhang, Z. Effect of controlled atmospheres with varying $\mathrm{O}_{2} / \mathrm{CO}_{2}$ levels on the postharvest senescence and quality of broccoli (Brassica oleracea L. Var. Italica) florets. Eur. Food Res. Technol. 2013, 237, 943-950. [CrossRef]

25. Fernandes, R.D.P.P.; de Alvarenga Freire, M.T.; de Paula, E.S.M.; Kanashiro, A.L.S.; Catunda, F.A.P.; Rosa, A.F.; de Carvalho Balieiro, J.C.; Trindade, M.A. Stability of lamb loin stored under refrigeration and packed in different modified atmosphere packaging systems. Meat Sci. 2014, 96, 554-561. [CrossRef] [PubMed]

26. Hendricks, M.T.; Hotchkiss, J.H. Effect of carbon dioxide on the growth of pseudomonas fluorescens and listeria monocytogenes in aerobic atmospheres. J. Food Prot. 1997, 12, 1548-1552. [CrossRef]

27. Jacxsens, L.; Devlieghere, F.; Steen, C.; Debevere, J. Effect of high oxygen modified atmosphere packaging on microbial growth and sensorial qualities of fresh-cut produce. Int. J. Food Microbiol. 2001, 2, 197-210. [CrossRef]

28. Kim, Y.H.; Huff-Lonergan, E.; Sebranek, J.G.; Lonergan, S.M. High-oxygen modified atmosphere packaging system induces lipid and myoglobin oxidation and protein polymerization. Meat Sci. 2010, 85, 759-767. [CrossRef]

29. Lagerstedt, Å.; Lundström, K.; Lindahl, G. Influence of vacuum or high-oxygen modified atmosphere packaging on quality of beef M. Longissimus Dorsi steaks after different ageing times. Meat Sci. 2011, 87, 101-106. [CrossRef] [PubMed]

30. Zakrys-Waliwander, P.I.; O'Sullivan, M.G.; O'Neill, E.E.; Kerry, J.P. The effects of high oxygen modified atmosphere packaging on protein oxidation of bovine M. longissimus dorsi muscle during chilled storage. Food Chem. 2012, 131, 527-532. [CrossRef]

31. Djenane, D.; Roncalés, P. Carbon monoxide in meat and fish packaging: Advantages and limits. Foods 2018, 7, 12. [CrossRef]

32. Seyfert, M.; Mancini, R.A.; Hunt, M.C.; Tang, J.; Faustman, C. Influence of carbon monoxide in package atmospheres containing oxygen on colour, reducing activity, and oxygen consumption of five bovine muscles. Meat Sci. 2007, 75, 432-442. [CrossRef] [PubMed]

33. Sørheim, O.; Westad, F.; Larsen, H.; Alvseike, O. Colour of ground beef as influenced by raw materials, addition of sodium chloride and low oxygen packaging. Meat Sci. 2009, 81, 467-473. [CrossRef] [PubMed]

34. Rogers, H.B.; Brooks, J.C.; Martin, J.N.; Tittor, A.; Miller, M.F.; Brashears, M.M. The impact of packaging system and temperature abuse on the shelf life characteristics of ground beef. Meat Sci. 2014, 97, 1-10. [CrossRef]

35. Van Rooyen, L.A.; Allen, P.; Kelly-Rees, C.; O'Connor, D.I. The effects of varying gas concentrations and exposure times on colour stability and shelf-life of vacuum packaged beef steaks subjected to carbon monoxide pretreatment. Food Packag. Shelf Life 2018, 18, 230-237. [CrossRef]

36. Hurme, E. Detecting Leaks in Modified Atmosphere Packaging. In Novel Food Packaging Techniques; Elsevier: Amsterdam, The Netherlands, 2003; pp. 276-286. ISBN 978-1-85573-675-7.

37. Hurme, E.U.; Ahvenainen, R. A Nondestructive leak detection method for flexible food packages using hydrogen as a tracer gas. J. Food Prot. 1998, 61, 1165-1169. [CrossRef] [PubMed]

38. Moghimi, N.; Sagi, H.; Park, S. Leakage analysis of flexible packaging: Establishment of a correlation between mass extraction leakage test and microbial ingress. Food Packag. Shelf Life 2018, 16, 225-231. [CrossRef]

39. Scarabottolo, N.; Fedel, M.; Cocola, L.; Poletto, L. In-line inspecting device for leak detection from gas-filled food packages. In Sensing for Agriculture and Food Quality and Safety XII; Kim, M.S., Cho, B.-K., Chin, B.A., Eds.; SPIE: Bellingham, WA, USA, 2020; p. 3.

40. Gorris, L.G.M.; Peppelenbos, H.W. Modified atmosphere and vacuum packaging to extend the shelf life of respiring food products. HortTechnology 1992, 2, 303-309. [CrossRef]

41. Wohner, B.; Pauer, E.; Heinrich, V.; Tacker, M. Packaging-related food losses and waste: An overview of drivers and issues. Sustainability 2019, 11, 264. [CrossRef]

42. Esmer, O.K.; Irkin, R.; Degirmencioglu, N.; Degirmencioglu, A. The effects of modified atmosphere gas composition on microbiological criteria, color and oxidation values of minced beef meat. Meat Sci. 2011, 88, 221-226. [CrossRef] [PubMed]

43. Narasimha Rao, D. Modified atmosphere and vacuum packaging of meat and poultry products. Food Rev. Int. 2002, 18, 263-293. [CrossRef]

44. Arvanitoyannis, I.S.; Stratakos, A.C. Application of modified atmosphere packaging and active/smart technologies to red meat and poultry: A review. Food Bioprocess Technol. 2012, 5, 1423-1446. [CrossRef]

45. Rubio, B.; Martínez, B.; González-Fernández, C.; García-Cachán, M.D.; Rovira, J.; Jaime, I. Effect of modified atmosphere packaging on the microbiological and sensory quality on a dry cured beef product: "Cecina de León". Meat Sci. 2007, 75, 515-522. [CrossRef]

46. Damian, F.; Geert, G.; Costa Alvarenga, T.I.R.; Polkinghorne, R.J.; Stark, J.L.; Warner, R.D. Impact of high oxygen and vacuum retail ready packaging formats on lamb loin and topside eating quality. Meat Sci. 2017, 123, 126-133. [CrossRef] 
47. Lindahl, G.; Lagerstedt, Å.; Ertbjerg, P.; Sampels, S.; Lundström, K. Ageing of large cuts of beef loin in vacuum or high oxygen modified atmosphere-Effect on shear force, calpain activity, desmin degradation and protein oxidation. Meat Sci. 2010, 85, 160-166. [CrossRef]

48. Zhang, X.; Wang, H.; Li, N.; Li, M.; Xu, X. High $\mathrm{CO}_{2}$-modified atmosphere packaging for extension of shelf-life of chilled yellow-feather broiler meat: A special breed in Asia. LWT-Food Sci. Technol. 2015, 64, 1123-1129. [CrossRef]

49. Stetzer, A.J.; Wicklund, R.A.; Paulson, D.D.; Tucker, E.M.; Macfarlane, B.J.; Brewer, M.S. effect of carbon monoxide and high oxygen modified atmosphere packaging (Map) on quality characteristics of beef strip steaks. J. Muscle Foods 2007, 18, 56-66. [CrossRef]

50. Fraqueza, M.J.; Barreto, A.S. The effect on Turkey meat shelf life of modified-atmosphere packaging with an argon mixture. Poult. Sci. 2009, 9, 1991-1998. [CrossRef]

51. Martínez, L.; Cilla, I.; Beltrán, J.A.; Roncalés, P. Effect of illumination on the display life of fresh pork sausages packaged in modified atmosphere. Influence of the addition of rosemary, ascorbic acid and black pepper. Meat Sci. 2007, 75, 443-450. [CrossRef] [PubMed]

52. Mastromatteo, M.; Incoronato, A.L.; Conte, A.; Del Nobile, M.A. Shelf life of reduced pork back-fat content sausages as affected by antimicrobial compounds and modified atmosphere packaging. Int. J. Food Microbiol. 2011, 150, 1-7. [CrossRef]

53. Speranza, B. Use of desirability approach to predict the inhibition of Pseudomonas fluorescens, Shewanella putrefaciens and Photobacterium phosphoreum in fish fillets through natural antimicrobials and modified atmosphere packaging. Food Bioprocess Technol. 2013, 6, 2319-2330. [CrossRef]

54. De la Caba, K.; Guerrero, P.; Trung, T.S.; Cruz-Romero, M.; Kerry, J.-P.; Fluhr, J.; Maurer, M.; Kruijssen, F.; Albalat, A.; Bunting, S.; et al. From seafood waste to active seafood packaging: An emerging opportunity of the circular economy. J. Clean. Prod. 2019, 208, 86-98. [CrossRef]

55. Caleb, O.J.; Mahajan, P.V.; Al-Said, F.A.-J.; Opara, U.L. Modified atmosphere packaging technology of fresh and fresh-cut produce and the microbial consequences-A review. Food Bioprocess Technol. 2013, 6, 303-329. [CrossRef] [PubMed]

56. Conte, A.; Scrocco, C.; Lecce, L.; Mastromatteo, M.; Nobile, M.A.D. Ready-to-eat sweet cherries: Study on different packaging systems. Innov. Food Sci. Emerg. Technol. 2009, 10, 564-571. [CrossRef]

57. Galvis, J.A.; Arjona, H.; Fischer, G.; Martínez, R. Using modified atmosphere packaging for storing 'Van Dyke' mango (Mangifera indica L.) fruit. Agron. Colomb. 2005, 23, 7.

58. Pesis, E.; Aharoni, D.; Aharon, Z.; Ben-Arie, R.; Aharoni, N.; Fuchs, Y. Modified atmosphere and modified humidity packaging alleviates chilling injury symptoms in mango fruit. Postharvest Biol. Technol. 2000, 19, 93-101. [CrossRef]

59. Superlan; Kazuhiko, I. Combined effects of hot water treatment (HWT) and modified atmosphere packaging (MAP) on quality of tomatoes. Packag. Technol. Sci. 2003, 16, 171-178. [CrossRef]

60. Tano, K.; Oulé, M.K.; Doyon, G.; Lencki, R.W.; Arul, J. Comparative evaluation of the effect of storage temperature fluctuation on modified atmosphere packages of selected fruit and vegetables. Postharvest Biol. Technol. 2007, 46, 212-221. [CrossRef]

61. Plestenjak, A.; Hribar, J.; Unuk, T.; Vidrih, R. Regulation of metabolic changes in shredded cabbage by modified atmosphere packaging. Food Technol. Biotechnol. 2008, 4, 427-433.

62. Wu, Z.; Zhang, M.; Wang, S. Effects of high-pressure argon and nitrogen treatments on respiration, browning and antioxidant potential of minimally processed pineapples during shelf life. J. Sci. Food Agric. 2012, 92, 2250-2259. [CrossRef] [PubMed]

63. Neuwald, D.A.; Saquet, A.A.; Klein, N. Disorders during Storage of Fruits and Vegetables. In Postharvest Physiological Disorders in Fruits and Vegetables; Tonetto de Freitas, S., Pareek, S., Eds.; CRC Press: Boca Raton, FL, USA, 2018; pp. 89-110. ISBN 978-1-315-26747-0.

64. Cliffe, V.; Mc Laughlin, C.P.; O'Beirne, D. The effects of packaging film and storage temperature on the quality of a dry coleslaw mix packaged in a modified atmosphere. Int. J. Food Sci. Tech. 2003, 38, 187-199. [CrossRef]

65. Sicari, V.; Dorato, G.; Giuffrè, A.M.; Rizzo, P.; Albunia, A.R. The effect of different packaging on physical and chemical properties of oranges during storage. J. Food Process. Preserv. 2017, 41, e13168. [CrossRef]

66. Rizzo, P.; Cozzolino, A.; Albunia, A.R.; Giuffrè, A.M.; Sicari, V.; Di Maio, L.; Daniel, C.; Venditto, V.; Galimberti, M.; Mensitieri, G.; et al. Packaging technology for improving shelf-life of fruits based on a nanoporous-crystalline polymer: Research article. J. Appl. Polym. Sci. 2018, 135, 46256. [CrossRef]

67. Giuffrè, A.M.; Louadj, L.; Rizzo, P.; Poiana, M.; Sicari, V. Packaging and storage condition affect the physicochemical properties of red raspberries (Rubus idaeus L., Cv. Erika). Food Control 2019, 97, 105-113. [CrossRef]

68. Giuffrè, A.M.; Louadj, L.; Rizzo, P.; De Salvo, E.; Sicari, V. The influence of film and storage on the phenolic and antioxidant properties of red raspberries (Rubus idaeus L.) Cv. Erika. Antioxidants 2019, 8, 254. [CrossRef]

69. Stelzig, D. Physiology and Pathology of Fruits and Vegetables. In Postharvest Pathology of Fruits and Vegetables: Postharvest Losses in Perishable Crops; Moline, H.E., Ed.; California Agricultural Experiment Station: Berkeley, CA, USA, 1984; pp. $36-41$.

70. Bourke, P.; O'Beirne, D. Effects of packaging type, gas atmosphere and storage temperature on survival and growth of Listeria spp. in shredded dry coleslaw and its components. Int. J. Food Sci. Technol. 2004, 39, 509-523. [CrossRef]

71. Shayanfar, S.; Kashaninejad, M.; Khomeiri, M.; Emam Djomeh, Z.; Mostofi, Y. Effect of MAP and different atmospheric conditions on the sensory attributes and shelf life characteristics of fresh pistachio nuts. Int. J. Nuts Relat. Sci. 2011, 2, 47-57.

72. The Ultimate Combination for Freshness. MAPAX®Modified Atmosphere Packaging; Linde-Gas: Pullach, Germany, 2005. 
73. Franz, C.M.; den Besten, H.M.; Böhnlein, C.; Gareis, M.; Zwietering, M.H.; Fusco, V. Microbial food safety in the 21st century: Emerging challenges and foodborne pathogenic bacteria. Trends Food Sci. Technol. 2018, 81, 155-158. [CrossRef]

74. Al-Haddad, K.S.H.; Al-Qassemi, R.A.S.; Robinson, R.K. The use of gaseous ozone and gas packaging to control populations of Salmonella infantis and Pseudomonas aeruginosa on the skin of chicken portions. Food Control 2005, 5, 405-410. [CrossRef]

75. Hulánková, R.; Bořilová, G.; Steinhauserová, I. Influence of modified atmosphere packaging on the survival of Salmonella enteritidis PT 8 on the surface of chilled chicken legs. Acta Vet. Brno 2010, 79, S127-S132. [CrossRef]

76. Bari, L.; Grumezescu, A.; Ukuku, D.O.; Dey, G.; Miyaji, T. New food processing technologies and food safety. J. Food Qual. 2017, 2017, 3535917. [CrossRef]

77. Nissen, H.; Alvseike, O.; Bredholt, S.; Holck, A.; Nesbakken, T. Comparison between the growth of Yersinia enterocolitica, Listeria monocytogenes, Escherichia coli O157:H7 and Salmonella spp. in ground beef packed by three commercially used packaging techniques. Int. J. Food Microbiol. 2000, 59, 211-220. [CrossRef]

78. Elkhishin, M.T.; Gooneratne, R.; Hussain, M.A. Microbial safety of foods in the supply chain and food security. Adv. Food Technol. Nutr. Sci. Open J. 2017, 3, 22-32. [CrossRef]

79. Ramamoorthi, L.; Toshkov, S.; Brewer, M.S. Effects of carbon monoxide-modified atmosphere packaging and irradiation on E. coli K12 survival and raw beef quality. Meat Sci. 2009, 83, 358-365. [CrossRef]

80. Humphrey, T.; O’Brien, S.; Madsen, M. Campylobacters as zoonotic pathogens: A food production perspective. Int. J. Food Microbiol. 2007, 117, 237-257. [CrossRef]

81. Tewari, A.; Abdullah, S. Bacillus cereus food poisoning: International and Indian perspective. J. Food Sci. Technol. 2015, 52, 2500-2511. [CrossRef]

82. Foodborne Pathogens: Hazards, Risk Analysis and Control, 1st ed.; de Blackburn, C., McClure, P., Eds.; CRC Press: Boca Raton, FL, USA; Cambridge, UK, 2002; ISBN 978-0-8493-1213-7.

83. Bottone, E.J. Bacillus cereus, a volatile human pathogen. Clin. Microbiol. Rev. 2010, 23, 382-398. [CrossRef]

84. Kotiranta, A.; Lounatmaa, K.; Haapasalo, M. Epidemiology and pathogenesis of Bacillus cereus infections. Microbes Infect. 2000, 2, 189-198. [CrossRef]

85. Ash, C.; Farrow, J.A.E.; Dorsch, M.; Stackebrandt, E.; Collins, M.D. Comparative analysis of Bacillus anthracis, Bacillus cereus, and related species on the basis of reverse transcriptase sequencing of 16S RRNA. Int. J. Syst. Bacteriol. 1991, 41, 343-346. [CrossRef]

86. Ahmed, A.A.-H.; Moustafa, M.K.; Marth, E.H. Incidence of Bacillus cereus in milk and some milk products. J. Food Prot. 1983, 46, 126-128. [CrossRef] [PubMed]

87. Barkley, M.B.; Delaney, P. An occurrence of bitty cream in australian pasteurized milk. Neth. Milk Dairy J. 1980, 34, $191-198$.

88. Goepfert, J.M.; Spira, W.M.; Kim, H.U. Bacillus cereus: Food poisoning organism. A review. J. Milk Food Technol. 1972, 35, 213-227. [CrossRef]

89. Fagerlund, A.; Lindbäck, T.; Granum, P.E. Bacillus cereus cytotoxins Hbl, Nhe and CytK are secreted via the sec translocation pathway. BMC Microbiol. 2010, 10, 304. [CrossRef]

90. Stenfors Arnesen, L.P.; Fagerlund, A.; Granum, P.E. From soil to gut: Bacillus cereus and its food poisoning toxins. FEMS Microbiol. Rev. 2008, 32, 579-606. [CrossRef]

91. Svensson, B. Characterisation of Bacillus cereus isolated from milk silo tanks at eight different dairy plants. Int. Dairy J. 2004, 14, 17-27. [CrossRef]

92. Choo, E.; Jang, S.S.; Kim, K.; Lee, K.-G.; Heu, S.; Ryu, S. Prevalence and genetic diversity of Bacillus cereus in dried red pepper in Korea. J. Food Prot. 2007, 70, 917-922. [CrossRef] [PubMed]

93. Kim, H.J.; Baek, S.-Y.; Lee, N.; Oh, S.-W. Organic acid resistance and toxin gene profiles of B. cereus isolated from red pepper powder: Acid resistance and toxin gene of B. cereus. J. Food Saf. 2013, 33, 319-326. [CrossRef]

94. Pui, C.F.; Wong, W.C.; Chai, L.C.; Lee, H.Y.; Tang, J.Y.H.; Noorlis, A.; Farinazleen, M.G.; Cheah, Y.K.; Son, R. Biofilm formation by salmonella typhi and salmonella typhimurium on plastic cutting board and its transfer to dragon fruit. Int. Food Res. J. 2011, 18, 31-38.

95. Pui, C.F.; Wong, W.C.; Chai, L.C.; Tunung, R.; Jeyaletchumi, P.; Noor Hidayah, M.S.; Ubong, A.; Farinazleen, M.G.; Cheah, Y.K.; Son, R. Salmonella: A foodborne pathogen. Int. Food Res. J. 2011, 18, 465-473.

96. Wattinger, L.; Stephan, R.; Layer, F.; Johler, S. Comparison of Staphylococcus aureus isolates associated with food intoxication with isolates from human nasal carriers and human infections. Eur. J. Clin. Microbiol. Infect. Dis. 2012, 31, 455-464. [CrossRef]

97. Lina, G.; Bohach, G.A.; Nair, S.P.; Hiramatsu, K.; Jouvin-Marche, E.; Mariuzza, R. International nomenclature committee for staphylococcal superantigens standard nomenclature for the superantigens expressed by staphylococcus. J. Infect. Dis. 2004, 189, 2334-2336. [CrossRef] [PubMed]

98. Muredzi, P. Active, Intelligent and Modified Atmosphere Packaging: A Model Technology for the Food Industry. Available online: https://www.researchgate.net/publication/264787890_Active_Intelligent_and_Modified_Atmosphere_Packaging_A_ Model_Technology_for_the_Food_Industry (accessed on 17 November 2019).

99. Brody, A.; Strupinsky, E.; Kline, L. Active Packaging for Food Applications; CRC Press: Boca Raton, FL, USA, 2001; ISBN 978-1-58716-045-5.

100. Brody, A.L. Commercial Uses of Active Food Packaging and Modified Atmosphere Packaging Systems. In Innovations in Food Packaging; Elsevier: Amsterdam, The Netherlands, 2005; pp. 457-474. ISBN 978-0-12-311632-1.

101. Kruijf, N.D.; Beest, M.V.; Rijk, R.; Sipiläinen-Malm, T.; Losada, P.P.; Meulenaer, B.D. Active and intelligent packaging: Applications and regulatory aspects. Food Addit. Contam. 2002, 19, 144-162. [CrossRef] 
102. Appendini, P.; Hotchkiss, J.H. Review of antimicrobial food packaging. Innov. Food Sci. Emerg. Technol. 2002, 3, 113-126. [CrossRef]

103. Peelman, N.; Peelman, N.; Ragaert, P.; Vandemoortele, A.; Verguldt, E.; De Meulenaer, B.; Devlieghere, F. Use of Biobased Materials for modified atmosphere packaging of short and medium shelf-life food products. Innov. Food Sci. Emerg. Technol. 2014, 26, 319-329. [CrossRef]

104. Mane, K.A. A review on active packaging: An innovation in food packaging. Int. J. Environ. Agric. Biotechnol. 2016, 1, 544-549. [CrossRef]

105. Butnaru, E.; Stoleru, E.; Brebu, M.; Darie-Nita, R.; Bargan, A.; Vasile, C. Chitosan-based bionanocomposite films prepared by emulsion technique for food preservation. Materials 2019, 12, 373. [CrossRef]

106. Vargas, M.; Sánchez-González, L.; Cháfer, M.; Chiralt, A.; González-Martínez, C. Edible Chitosan Coatings for Fresh and Minimally Processed Foods. In Emerging Food Packaging Technologies; Elsevier: Amsterdam, The Netherlands, $2012 ;$ pp. 66-95. ISBN 978-1-84569-809-6.

107. Marudova, M.; Lang, S.; Brownsey, G.J.; Ring, S.G. Pectin-chitosan multilayer formation. Carbohydr. Res. 2005, 340, 2144-2149. [CrossRef]

108. Kim, K.W. Antimicrobial activity against foodborne pathogens of chitosan biopolymer films of different molecular weights. LWT-Food Sci. Technol. 2011, 44, 565-569. [CrossRef]

109. No, H.K.; Park, N.Y.; Lee, S.H.; Meyers, S.P. Antibacterial activity of chitosans and chitosan oligomers with different molecular weights. Int. J. Food Microbiol. 2002, 74, 65-72. [CrossRef]

110. Dobrucka, R.; Cierpiszewski, R. Active and intelligent packaging food-Research and development-A Review. Pol. J. Food Nutr. Sci. 2014, 64, 7-15. [CrossRef]

111. Li, J.; Zivanovic, S.; Davidson, P.M.; Kit, K. Characterization and comparison of chitosan/PVP and chitosan/PEO blend films. Carbohydr. Polym. 2010, 79, 786-791. [CrossRef]

112. Vasile, C.; Rapa, M.; Stefan, M.; Stan, M.; Macavei, S.; Darie-Nita, R.N.; Barbu-Tudoran, L.; Vodnar, D.C.; Popa, E.E.; Stefan, R.; et al. New PLA/ZnO:Cu/Ag Bionanocomposites for food packaging. Express Polym. Lett. 2017, 11, 531-544. [CrossRef]

113. Yoksan, R.; Chirachanchai, S. Silver nanoparticle-loaded chitosan-starch based films: Fabrication and evaluation of tensile, barrier and antimicrobial properties. Mater. Sci. Eng. C 2010, 6, 891-897. [CrossRef]

114. Pal, M.; Devrani, M.; Hadush, A. Recent developments in food packging technologies. Beverage Food World 2019, 1, 21-25. 